\title{
Polymeric glabrescione B nanocapsules for passive targeting of Hedgehog-dependent tumor therapy in vitro
}

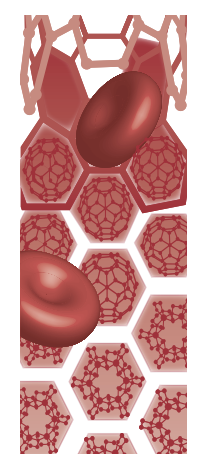

\begin{abstract}
Aim: With the purpose of delivering high doses of glabrescione B (GlaB) to solid tumors after systemic administration, long-circulating GlaB-loaded oil-cored polymeric nanocapsules (NC-GlaB) were formulated. Materials \& methods: Synthesis of GlaB and its encapsulation in nanocapsules (NCs) was performed. Empty and GlaBloaded NCs were assessed for their physico-chemical properties, in vitro cytotoxicity and in vivo biodistribution. Results: GlaB was efficiently loaded into NCs ( 90\%), which were small $(\sim 160 \mathrm{~nm})$, homogeneous and stable upon storage. Further, GlaB and NC-GlaB demonstrated specific activities against the cancer stem cells. Preliminary studies in tumor-bearing mice supported the ability of NC to accumulate in pancreatic tumors. Conclusion: This study provides early evidence that NC-GlaB has the potential to be utilized in a preclinical setting and justifies the need to perform therapeutic experiments in mice.
\end{abstract}

First draft submitted: 7 November 2016; Accepted for publication: 26 January 2017; Published online: 21 March 2017

Keywords: glabrescione B (GlaB) • Hedgehog (Hh) pathway • oil-cored polymeric nanocapsules

Cancer stem cells (CSCs) represent a subpopulation of stem cells within a tumor which drive growth and metastasis. While chemotherapy and radiation therapy are frequently able to eradicate most of the tumor bulk and proliferative cells, these treatments frequently fail in eradicating the quiescent CSCs, which might be dormant for years [1]. Eradication of the CSCs is thought to be essential to achieve complete tumor ablation and prevent cancer relapse [2]. Several signaling pathways that regulate normal stem cell self-renewal cause neoplastic proliferation when dysregulated by mutations [3]. Among those is the Hedgehog $(\mathrm{Hh})$ signaling pathway, which is essential for tissue development and stemness, and whose dysregulation leads to tumorigenesis [4]. Aberrant activation of the Hh pathway is responsible for the tumorigenesis of several human cancers including medulloblastoma (MB) [5], rhab- domyosarcoma [6,7], melanoma [8], basal cell carcinoma (BCC) [9], breast [10], liver [11], lung $[12,13]$, prostate $[14,15]$, brain and pancreas tumors [16-19]. Thus, this pathway has been widely targeted in recent years for the development of anticancer drugs. A recent study from the co-authors of this paper identified glabrescione B (GlaB) [20], a naturally occurring isoflavone in Derris glabrescens [21], as the first small molecule that binds the Hh modulator Gli1 (a zinc finger) and impairs its activity by interfering with Gli-DNA interaction. GlaB was shown to inhibit the in vitro and in vivo growths of multiple Hh-dependent cancer cells and CSCs, as well as the self-renewal ability and clonogenicity of tumor-derived stem cells [22]. In this previously reported study, the ability of $\mathrm{GlaB}$ against $\mathrm{MB}$ in the allograft model of MB cells by subcutaneous injection, using a solution of GlaB (75 $\mu \mathrm{mol} / \mathrm{kg}$ ) prepared in 2-hydroxypropyl- $\beta$ -
Cinzia Ingallina ${ }^{1,2}$, Pedro $M$ Costa', Francesca Ghirga ${ }^{3}$, Rebecca Klippstein', Julie T Wang ${ }^{1}$, Simone Berardozzi ${ }^{2,3}$, Naomi Hodgins', Paola Infante ${ }^{3}$, Steven M Pollard ${ }^{4}$, Bruno Botta ${ }^{*, 2}$ \& Khuloud T Al-Jamal**,1

'Institute of Pharmaceutical Science, Faculty of Life Sciences \& Medicine, King's College London, Franklin-Wilkins Building, London, SE1 9NH, UK Dipartimento di Chimica e Tecnologie del Farmaco, Sapienza Università di Roma, Rome, Italy

${ }^{3}$ Center for Life NanoScience@Sapienza, Istituto Italiano di Tecnologia, Rome, Italy ${ }^{4} \mathrm{MRC}$ Centre for Regenerative Medicine, University of Edinburgh, Edinburgh bioQuarter, 5 Little France Drive, Edinburgh EH16 4UU, UK *Author for correspondence: Tel.: +390649912781 Fax: +3906 49693323 bruno.botta@uniroma1.it **Author for correspondence: Tel.: +44207848 4525 khuloud.al-jamal@kcl.ac.uk 
cyclodextrin:ethanol (3:1), was assessed. During the 18-day treatment, GlaB significantly suppressed the tumor mass compared with the control. Despite the promising findings confirming the therapeutic efficacy of GlaB against Hh-dependent cancer, it was concluded that delivery approaches are required to solubilize GlaB in aqueous solvents so that systemic administration of relatively high doses is feasible.

Nanotechnology-based drug delivery systems offer the possibility of solubilizing poorly soluble drugs, protecting labile molecules and improving on tissue biodistribution [23]. Among the different drug delivery technologies, polymeric nanocapsules (NCs) have attracted growing attention due to the high loading capacity of hydrophobic molecules, as well as longterm stability, offering enhanced bioavailability of the active compound [24,25]. NCs consist of a core-shell structure made of hydrophilic polymer stabilized with lipophilic and/or hydrophilic surfactants surrounding an oily core, in which active molecules are confined [26]. Their preparation is generally cheap, fast and easily scalable.

This work focused on developing GlaB-loaded oilcored polymeric NCs to improve its water solubility, so that it targets Hh-dependent cancer cells in vitro and in vivo. The choice of this formulation was encouraged by our previous studies for the delivery of water-insoluble drugs such as quercetin [27] and curcumin [28]. Physico-chemical properties, including hydrodynamic diameter, polydispersity index (PDI), $\zeta$ potential and stability, were determined. Once the desired formulation was identified, the anticancer activity of both GlaB and $\mathrm{NC}-\mathrm{GlaB}$ was evaluated in vitro against a range of CSCs and non-CSCs, which have been reported to have a strong dependence on the Hh pathway. Finally, the in vivo biodistribution profile and organ histology of intravenously administered NC-GlaB was assessed in pancreatic-tumor-bearing mice. Overall, this study provides early evidence that NC-GlaB has the potential to be utilized in a preclinical setting, aiming at its future use in clinic.

\section{Materials \& methods}

Materials

SnakeSkin ${ }^{\mathrm{TM}}$ (10K molecular weight cut-off [MWCO] dialysis tubing) was acquired from ThermoFisher (CA, USA); soybean lecithin (Epikuron $140 \mathrm{~V}$ ) was a kind donation from Cargill Pharmaceuticals (MN, USA). Castor oil, Tween ${ }^{\circledR}$ 80, methylene chloride, absolute ethanol, DMSO and acetone were acquired from Sigma-Aldrich (UK). Bovine serum albumin solution $7.5 \%$ and $50 \mathrm{mM} \beta$-mercaptoethanol were purchased from ThermoFisher Scientific (UK). 75/25 DL-lactide/ glycolide conjugate (PLGA-COOH, $\mathrm{M}_{\mathrm{w}} \approx 18,000$ ) was a gift from Purac Biomaterials (The Netherlands). PLGA-NH-PEG and PLGA-NH-PEG-NH-DTPA were synthesized as we previously described [27,28]. The radioactivity tracer $\left[{ }^{111} \mathrm{In}\right] \mathrm{Cl}_{3}$ (aqueous solution) was obtained from Convidien UK Commercial LTD (UK) and was used without prior purification. TLC strips for radiolabeling were acquired from Agilent Technologies UK Ltd (UK) and flow cytometry tubes were obtained from VWR (UK).

\section{Synthesis of GlaB}

2'-hydroxy-4',6'-dimethoxyacetophenone 1

A flame-dried flask was charged with $2^{\prime}, 4^{\prime}, 6^{\prime}$-trimethoxyacetophenone $(5 \mathrm{~g}, 23.8 \mathrm{mmol}$; Sigma-Aldrich 630594) and dry $\mathrm{CH}_{2} \mathrm{Cl}_{2}(75 \mathrm{ml})$ under argon. $\mathrm{BBr}_{3}$ $(15 \mathrm{ml}, 87.3 \mathrm{mmol}$ ) was added drop wise. The resulting solution was stirred at room temperature for $2 \mathrm{~h}$ before adding $4 \mathrm{M} \mathrm{NaOH}(90 \mathrm{ml})$ and allowed to stand for $30 \mathrm{~min}$. The solution was extracted with $\mathrm{CH}_{2} \mathrm{Cl}_{2}$ and combined organic layers were washed with brine, dried over $\mathrm{Na}_{2} \mathrm{SO}_{4}$ and finally concentrated under reduced pressure. The resulting solid was recrystallized from EtOH and white crystals of 2'-hydroxy-4',6'dimethoxyacetophenone 1 (4.43 g) were obtained.

White solid (yield 98\%); melting point (mp) 81-82 ${ }^{\circ} \mathrm{C}$; ${ }^{1} \mathrm{H}$ NMR $\left(400 \mathrm{MHz}\right.$, acetone- $\left.\mathrm{d}_{6}, \delta\right): 13.8$ $(\mathrm{s}, 1 \mathrm{H}, \mathrm{OH}), 5.94(\mathrm{~d}, \mathrm{~J}=2.4 \mathrm{~Hz}, 1 \mathrm{H}, \operatorname{Ar~H}), 5.91(\mathrm{~d}$, $\mathrm{J}=2.4 \mathrm{~Hz}, 1 \mathrm{H}, \mathrm{Ar} \mathrm{H}), 3.80\left(\mathrm{~s}, 3 \mathrm{H}, \mathrm{OCH}_{3}\right), 3.72(\mathrm{~s}$, $\left.3 \mathrm{H}, \mathrm{OCH}_{3}\right), 2.43\left(\mathrm{~s}, 3 \mathrm{H}, \mathrm{CH}_{3}\right) ;{ }^{13} \mathrm{C} \mathrm{NMR}(100 \mathrm{MHz}$,

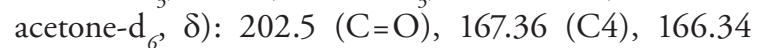
(C6), 163.15 (C2), 105.5 (C1), 93.42 (C3), 90.43 (C5), $55.20\left(\mathrm{OCH}_{3}\right), 55.00\left(\mathrm{OCH}_{3}\right), 31.94\left(\mathrm{CH}_{3}\right)$; IR $(\mathrm{KBr}): v=3100,1614,1271 \mathrm{~cm}^{-1}$; high-resolution mass spectrometry (HRMS; ESI) m/z: $[\mathrm{M}+\mathrm{H}]^{+}$calculated for $\mathrm{C}_{10} \mathrm{H}_{12} \mathrm{O}_{4}+\mathrm{H}^{+}, 197.080800$; found, 197.080848 .

\section{3-dimethylamino-1-(2-hydroxy-4,6-} dimethoxyphenyl) propenone 2

A mixture of 2'-hydroxy-4', $6^{\prime}$-dimethoxyacetophenone $1(4.5 \mathrm{~g}, 22.9 \mathrm{mmol})$ and $\mathrm{N}, \mathrm{N}-$ dimethylformamide dimethylacetal $(13 \mathrm{ml}, 97.1 \mathrm{mmol})$ was heated at $95^{\circ} \mathrm{C}$ for $3 \mathrm{~h}$. Afterward, the solvent was removed under reduced pressure and the obtained $\mathbf{2}(5.8 \mathrm{~g})$ was used in the subsequent step without any further purification.

Red solid (quantitative yield); mp $145-147^{\circ} \mathrm{C} ;{ }^{1} \mathrm{H}$ $\operatorname{NMR}\left(400 \mathrm{MHz}, \mathrm{CDCl}_{3}, \delta\right): 15.65(\mathrm{~s}, 1 \mathrm{H}, \mathrm{OH}), 7.92$ $(\mathrm{d}, \mathrm{J}=12 \mathrm{~Hz}, 1 \mathrm{H},=\mathrm{CH}-\mathrm{N}), 6.25(\mathrm{~d}, \mathrm{~J}=12.0 \mathrm{~Hz}, 1 \mathrm{H}$, $=\mathrm{CH}-(\mathrm{CO}), 6.07(\mathrm{~d}, \mathrm{~J}=2.4 \mathrm{~Hz}, 1 \mathrm{H}, \mathrm{Ar} \mathrm{H}), 5.91(\mathrm{~d}, \mathrm{~J}$ $=2.4 \mathrm{~Hz}, 1 \mathrm{H}, \mathrm{Ar} \mathrm{H}), 3.84\left(\mathrm{~s}, 3 \mathrm{H}, \mathrm{OCH}_{3}\right), 3.80(\mathrm{~s}, 3 \mathrm{H}$, $\left.\mathrm{OCH}_{3}\right), 3.15\left(\mathrm{~s}, 3 \mathrm{H}, \mathrm{NCH}_{3}\right), 2.92\left(\mathrm{~s}, 3 \mathrm{H}, \mathrm{NCH}_{3}\right) ;{ }^{13} \mathrm{C}$ NMR (100 MHz, $\left.\mathrm{CDCl}_{3}, \delta\right): 191.64(\mathrm{C}=\mathrm{O}), 169.00$ (C4), 165.54 (C6), $162.86(\mathrm{C} 2), 155.83(\mathrm{CH}-\mathrm{N})$, $106.58(\mathrm{C} 1), 96.27(\mathrm{CH}-(\mathrm{CO})), 95.59(\mathrm{C} 3), 92.06$ (C5), $57.09\left(\mathrm{OCH}_{3}\right), 56.57\left(\mathrm{OCH}_{3}\right)$; IR (KBr): $v=$ 
3447, 1614, 1542, $1362 \mathrm{~cm}^{-1}$; ESI-MS m/z: $[\mathrm{M}+\mathrm{H}]^{+}$ calculated for $\mathrm{C}_{13} \mathrm{H}_{17} \mathrm{O}_{4} \mathrm{~N}+\mathrm{H}^{+}$, 252.1; found, 252.3.

\section{3-iodo-5,7-dimethoxy-4H-chromen-4-one 3}

The enamino ketone 2 was dissolved in $\mathrm{CH}_{3} \mathrm{OH}$ ( 450 $\mathrm{ml})$ and $\mathrm{I}_{2}(11.7 \mathrm{~g}, 46.2 \mathrm{mmol})$ was added to the solution. The mixture was stirred at room temperature for $1 \mathrm{~h}$, then the solvent was evaporated. To remove residual $\mathrm{I}_{2}$, the crude was treated with a saturated aqueous $\mathrm{Na}_{2} \mathrm{~S}_{2} \mathrm{O}_{3}$ solution until the mixture became clear. The mixture was then extracted with $\mathrm{CHCl}_{3}$, and the combined organic layers were dried over $\mathrm{Na}_{2} \mathrm{SO}_{4}$ and concentrated under reduced pressure. The residue was purified by column chromatography using hexane-EtOAc as eluent to obtain 3-iodo-5,7-dimethoxy$4 \mathrm{H}$-chromen-4-one $3(2.5 \mathrm{~g})$ as a white powder.

White solid (yield $33 \%$ ); mp $156-157^{\circ} \mathrm{C} ;{ }^{1} \mathrm{H}$ NMR $\left(400 \mathrm{MHz}, \mathrm{CDCl}_{3}, \delta\right): 8.02$ (s, 1H, H-2), 6.37 (d, J $=2.0 \mathrm{~Hz}, 1 \mathrm{H}, \operatorname{Ar~H}), 6.32(\mathrm{~d}, \mathrm{~J}=2.0 \mathrm{~Hz}, 1 \mathrm{H}, \operatorname{Ar~H})$, $3.87\left(\mathrm{~s}, 3 \mathrm{H}, \mathrm{OCH}_{3}\right), 3.82\left(\mathrm{~s}, 3 \mathrm{H}, \mathrm{OCH}_{3}\right) ;{ }^{13} \mathrm{C} \mathrm{NMR}$ $\left(100 \mathrm{MHz}, \mathrm{CDCl}_{3}, \delta\right): 183.43(\mathrm{C}=\mathrm{O}), 164.28$ (C7), 160.97 (C5), 159.81 (C9), 155.33 (C2), 107.53 (C10), 96.59 (C8), 92.44 (C6), $89.71(=\mathrm{C}-\mathrm{I}), 56.41\left(\mathrm{OCH}_{3}\right)$, $55.79\left(\mathrm{OCH}_{3}\right)$; IR $(\mathrm{KBr}): v=1671,1640,1600-1450$ $\mathrm{cm}^{-1}$; HRMS (ESI) $\mathrm{m} / \mathrm{z}$ : $[\mathrm{M}+\mathrm{H}]^{+}$calculated for $\mathrm{C}_{11} \mathrm{H}_{9} \mathrm{O}_{4} \mathrm{I}+\mathrm{H}^{+}, 332.961800$; found, 332.961633 .

3-(3',4'-methylendioxyphenyl)-5,7-dimethoxy-4Hchromen-4-one 4

To a solution of $3(2.5 \mathrm{~g}, 7.5 \mathrm{mmol})$, in 1,2-dimethoxyethane $/ \mathrm{H}_{2} \mathrm{O}=50: 50(150 \mathrm{ml})$ were added $\mathrm{Na}_{2} \mathrm{CO}_{3}$ (3.18 g, $30 \mathrm{mmol}$ ), 3,4-(methylenedioxy)-phenylboronic acid $(1.8 \mathrm{~g}, 11 \mathrm{mmol})$ and $\mathrm{Pd} \mathrm{EnCat}{ }^{\mathrm{TM}} 40(937$ $\mathrm{mg}, 5 \%)$. The resulting mixture was stirred at $45^{\circ} \mathrm{C}$ for $2 \mathrm{~h}$ and then filtered. The catalyst was washed with $\mathrm{H}_{2} \mathrm{O}$ and $\mathrm{CH}_{2} \mathrm{Cl}_{2}$. The aqueous phase was extracted with $\mathrm{CH}_{2} \mathrm{Cl}_{2}$. The combined organic layers were dried over $\mathrm{Na}_{2} \mathrm{SO}_{4}$ and concentrated under reduced pressure. The crude residue was purified by flash chromatography using hexane-EtOAc as eluent to give $\mathbf{4}(1.4 \mathrm{~g})$ as a gray powder.

Gray solid (yield 57\%); mp: $155-156^{\circ} \mathrm{C} ;{ }^{1} \mathrm{H}$ NMR $\left(400 \mathrm{MHz}, \mathrm{CDCl}_{3}, \delta\right): 7.75$ (s, $\left.1 \mathrm{H}, \mathrm{H}-2\right), 7.1$ (d, J $\left.=2.0 \mathrm{~Hz}, 1 \mathrm{H}, \mathrm{H}-2^{\prime}\right), 6.94(\mathrm{dd}, \mathrm{J}=8.0$ and $2.0 \mathrm{~Hz}$, $\left.1 \mathrm{H}, \mathrm{H}-\mathrm{G}^{\prime}\right), 6.83\left(\mathrm{~d}, \mathrm{~J}=8.0 \mathrm{~Hz}, 1 \mathrm{H}, \mathrm{H}-5^{\prime}\right), 6.44$ (d, J $=2.2 \mathrm{~Hz}, 1 \mathrm{H}, \mathrm{H}-6), 6.37(\mathrm{~d}, \mathrm{~J}=2.2 \mathrm{~Hz}, 1 \mathrm{H}, \mathrm{H}-8)$, 5.97 (brs, $\left.2 \mathrm{H}, \mathrm{O}-\mathrm{CH}_{2}-\mathrm{O}\right), 3.94\left(\mathrm{~s}, 3 \mathrm{H}, \mathrm{OCH}_{3}\right)$, $3.89\left(\mathrm{~s}, 3 \mathrm{H}, \mathrm{OCH}_{3}\right) ;{ }^{13} \mathrm{C}$ NMR $\left(100 \mathrm{MHz}, \mathrm{CDCl}_{3}\right.$,

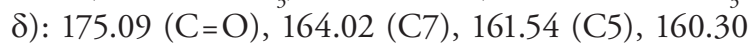
(C9), 150.05 (C2), 147.58 (C3'), 147.58 (C4'), 126.5 (C3), $126.04\left(\mathrm{C1}^{\prime}\right), 122.84\left(\mathrm{C6}^{\prime}\right), 110.50\left(\mathrm{C}^{\prime}\right), 110.0$ (C10), 108.35 (C5'), $101.30\left(\mathrm{O}-\mathrm{CH}_{2}-\mathrm{O}\right), 96.74$ (C6), $92.73(\mathrm{C} 8), 56.41\left(\mathrm{OCH}_{3}\right), 55.79\left(\mathrm{OCH}_{3}\right)$; IR $(\mathrm{KBr}): v=1654,1456,1247 \mathrm{~cm}^{-1}$; HRMS (ESI) m/z:
$[\mathrm{M}+\mathrm{H}]^{+}$calculated for $\mathrm{C}_{18} \mathrm{H}_{14} \mathrm{O}_{6}+\mathrm{H}^{+}, 327.086300$; found, 327.086206.

\section{3-(3',4'-dihydroxyphenyl)-5,7-dimethoxy-4H-} chromen-4-one 5

A mixture of $4(1.4 \mathrm{~g}, 4.3 \mathrm{mmol})$ and $\mathrm{Pb}(\mathrm{OAc})_{4}$ (7.5 $\mathrm{g}, 17 \mathrm{mmol}$, freshly recrystallized from $\mathrm{AcOH})$ in dry $\mathrm{C}_{6} \mathrm{H}_{6}(100 \mathrm{ml})$ was stirred at $80^{\circ} \mathrm{C}$ under argon overnight. After, being cooled to room temperature, the reaction mixture was filtered through a pad of Celite, washed with $\mathrm{CH}_{2} \mathrm{Cl}_{2}$ and concentrated under reduced pressure. The crude was diluted with $\mathrm{THF} / \mathrm{H}_{2} \mathrm{O}=$ 5:1 $(50 \mathrm{ml})$ and $\mathrm{CH}_{3} \mathrm{COOH}(50 \mathrm{ml})$, and the resulting mixture was stirred at room temperature for $6 \mathrm{~h}$. Afterward, a saturated aqueous $\mathrm{NaHCO}_{3}$ solution was added until $\mathrm{pH} 8$ and extracted with EtOAc. To the combined organic layers was added a solution of $\mathrm{NaOH}$ $0.1 \mathrm{M}$. Water layer was treated with $\mathrm{CH}_{3} \mathrm{COOH}$ and then extracted with EtOAc. The combined organic layers were dried over $\mathrm{Na}_{2} \mathrm{SO}_{4}$ and concentrated under reduced pressure to obtain $\mathbf{5}(570 \mathrm{mg})$.

Yellow solid (yield 42\%); mp: $127-129^{\circ} \mathrm{C}$; ${ }^{1} \mathrm{H}$ NMR (400 MHz, $\mathrm{CH}_{3} \mathrm{OD}$ ): 7.86 (s, 1H, H-2), 6.88 (brs, $\left.1 \mathrm{H}, \mathrm{H}-2^{\prime}\right), 6.70$ (brs, $2 \mathrm{H}, \mathrm{H}-5^{\prime}$ and $\left.\mathrm{H}-\mathrm{G}^{\prime}\right), 6.50(\mathrm{~d}, \mathrm{~J}$ $=2.0 \mathrm{~Hz}, 1 \mathrm{H}, \mathrm{H}-6), 6.40(\mathrm{~d}, \mathrm{~J}=2.0 \mathrm{~Hz}, 1 \mathrm{H}, \mathrm{H}-8)$, $3.80\left(\mathrm{~s}, 3 \mathrm{H}, \mathrm{OCH}_{3}\right), 3.79\left(\mathrm{~s}, 3 \mathrm{H}, \mathrm{OCH}_{3}\right) ;{ }^{13} \mathrm{C} \mathrm{NMR}$ (100 MHz, $\left.\mathrm{CH}_{3} \mathrm{OD}, \delta\right): 175.00(\mathrm{C}=\mathrm{O}), 165.08(\mathrm{C} 7)$, 161.13 (C5), 159.91 (C9), 151.28 (C2), 145.12 (C3'), 145.0 (C4'), 126.49 (C3), $123.12\left(\mathrm{C1}^{\prime}\right), 120.50\left(\mathrm{C}^{\prime}\right)$, 116.99 (C2'), 110.00 (C10), 114.48 (C5'), 95.86 (C6), $92.82(\mathrm{C} 8), 55.09\left(2 \times \mathrm{OCH}_{3}\right)$; IR $(\mathrm{KBr}): v=3376$, $1637 \mathrm{~cm}^{-1}$; HRMS (ESI) m/z: $[\mathrm{M}+\mathrm{H}]^{+}$calculated for $\mathrm{C}_{17} \mathrm{H}_{14} \mathrm{O}_{6}+\mathrm{H}^{+}$, 315.086300; found, 315.086363 .

3-(3',4'-bis (3-methylbut-2-enyloxy) phenyl)-5,7-dimethoxy-4H-chromen-4-one; GlaB. To a solution of 5 $(570 \mathrm{mg}, 61.8 \mathrm{mmol})$ in acetone $(100 \mathrm{ml})$ was added $\mathrm{K}_{2} \mathrm{CO}_{3}(7.4 \mathrm{~g}, 5.4 \mathrm{mmol})$ and, after $10 \mathrm{~min}$ of stirring at room temperature, was added 3,3-dimethylallyl bromide (968 mg, $6.5 \mathrm{mmol}$ ). Then, the mixture was stirred at $80^{\circ} \mathrm{C}$ overnight. Afterward, the solvent was evaporated. The resulting solid was dissolved in EtOAc and extracted with water. The combined organic layers were dried over $\mathrm{Na}_{2} \mathrm{SO}_{4}$ and finally concentrated under reduced pressure. The crude was purified by column chromatography using hexane-EtOAc as eluent to obtain GlaB as white powder. The powder was recrystallized from hexane resulting with white crystals.

White crystal (yield 90\%); mp $102-104^{\circ} \mathrm{C}$. The spectral data of this product were identical to an authentic sample of GlaB.

\section{Formulation of the NCs}

Encapsulation protocol

NC-GlaB were prepared by using three poly(lactic-co- 
glycolic acid) (PLGA) polymer derivatives: the commercially available PLGA, PEGylated PLGA (PLGA-PEG) conjugates capable of prolonged blood circulation profile and PLGA-PEG conjugated with diethylene triamine pentaacetic acid (DTPA; PLGAPEG-DTPA), which allows the tracking of NCs in vivo by $\gamma$ scintigraphy. NCs containing GlaB were prepared using the nanoprecipitation method described by Fessi et al. (Figure 1) [29]. Briefly, $2.5 \mathrm{ml}$ of acetone/ ethanol $(60: 40 \mathrm{v} / \mathrm{v})$ containing polymer (the commercially available PLGA [100\%], PLGA-NH-PEG [100\%] or PLGA-NH-PEG/PLGA-NH-PEGDTPA [90\%:10\%]) (12.5 mg), castor oil $(75 \mu \mathrm{l})$, GlaB ( $4 \mathrm{mg})$ and soybean lecithin $(12.5 \mathrm{mg})$ was added dropwise into $5 \mathrm{ml}$ of aqueous phase (containing $0.2 \%$ of hydrophilic surfactant Tween ${ }^{\circledR} 80$ ). The mixture was stirred in the hood for $30 \mathrm{~min}$ to allow solvent diffusion and NC formation. Subsequently, the organic solvents were removed via rotatory evaporation under reduced pressure in a Buchi Rotavapor ${ }^{\circledR}$ (Buchi, UK). Finally, the volume of suspension was adjusted to $5 \mathrm{ml}$.

\section{Solubility of GlaB in castor oil}

The solubility of GlaB in castor oil was evaluated using the simple saturation shake-flask method [30]. Briefly, excess $\mathrm{GlaB}(10 \mathrm{mg})$ was transferred to vials containing $1 \mathrm{ml}$ of castor oil, sealed and incubated at $37^{\circ} \mathrm{C}$ for $48 \mathrm{~h}$ with shaking (250 strokes/min). Subsequently, $100 \mu \mathrm{l}$ of the supernatant was diluted in ethanol, and the amount of GlaB dissolved in the organic solvent was determined using a UV-Vis spectrophotometer (UV-1601 PC, Shimadzu, Japan) by measuring the absorbance at $258 \mathrm{~nm}$, against a GlaB standard curve.

\section{Determination of GlaB encapsulation efficiency}

To purify the sample from un-encapsulated drug, NCs were passed through a PD10 desalting column (GE Healthcare). To disrupt the NCs and quantify the total amount of drug in NCs prior and after purification, NC preparations $(30 \mu \mathrm{l})$ were diluted in ethanol (to a final volume of $2 \mathrm{ml}$ ). Subsequently, the amount of $\mathrm{GlaB}$ in NCs was determined using a UV-Vis spectrophotometer (UV-1601 PC, Shimadzu) by measuring the absorbance at $258 \mathrm{~nm}$ against a standard plot of known GlaB concentrations. The amount of GlaB in the measured samples was then calculated from the standard plots (Supplementary materials) and the encapsulation efficiency (EE, \%) was calculated using the following equation:

$\mathrm{EE}(\%)=([$ Drug $]$ encapsulated $/[$ Drug $]$ total $) \times 100$

Drug loading efficiency (\% LE) was calculated using the following equation:
$\% \mathrm{LE}=$ amount of GlaB encapsulated $(\mathrm{mg}) /($ weight of polymer) $\times 100$

\section{Physico-chemical characterization of NCs}

Size \& $\zeta$ potential

The average size and $\zeta$ potential of the NCs were measured by dynamic light scattering with a Nanosizer ZS Series (Malvern Instruments, MA, USA), using disposable polystyrene cells and plain-folded capillary Zeta cells. Dilutions were prepared in deionized water and measurements performed at room temperature. The electrophoretic mobility was used to calculate the $\zeta$ potential using the Helmholtz-Smoluchowski equation. Results for the hydrodynamic size are presented as the average of 20 measurements, each performed in triplicate.

\section{Release profile \& serum stability in vitro} About $2 \mathrm{ml}$ of $\mathrm{NC}$ formulation containing $2 \mathrm{mg}$ (GlaB) in $5 \mathrm{ml}$ was transferred into a $10 \mathrm{kDa}$ dialysis bag, and dialysis was performed against $200 \mathrm{ml}$ of phosphatebuffered saline (PBS; pH 7.4) containing 10\% (w/v) Tween ${ }^{\circledR} 80$, at $37^{\circ} \mathrm{C}$ under stirring (250 strokes/min). Samples were taken after $24 \mathrm{~h}$, and drug concentration was determined using a Perkin-Elmer Lambda 35 UVVis spectrophotometer by measuring the absorbance at $258 \mathrm{~nm}$.

\section{Shelf life stability}

$\mathrm{NC}$ suspensions were transferred to $7 \mathrm{ml}$ glass vials, sealed and stored at $4^{\circ} \mathrm{C}$. The stability of NCs was tested after 0, 7, 14 and 28 days by visual inspection (color and opacity) and by measuring the hydrodynamic size and $\zeta$ potential. Results of measurements $(\mathrm{n}=3)$ are presented as average \pm standard deviation (SD).

\section{Cell culture}

SKOV3 human ovary adenocarcinoma cell line was cultured in McCoy media, while PANC1 human pancreatic carcinoma cell line and GL261 murine glioma cell line were cultured in Advanced Roswell Park Memorial Institute (RPMI) media (Sigma, MO, USA), at $37^{\circ} \mathrm{C}$ in $5 \% \mathrm{CO}_{2}$. Culture medium was supplemented with $10 \%$ fetal bovine serum (FBS), $100 \mathrm{U} /$ $\mathrm{ml}$ penicillin, $100 \mu \mathrm{g} / \mathrm{ml}$ streptomycin and $1 \% \mathrm{~L}$-glutamine (Sigma). Cells were routinely grown in $75 \mathrm{~cm}^{2}$ tissue culture flasks and passaged twice a week, after detachment with trypsin/EDTA (Sigma), when reaching $80 \%$ confluency.

Human (G7) and mouse glioma-initiating neural stem cell line (IENS) glioblastoma (GBM), as well as their culturing conditions, have been described previously [31-34]. Briefly, cells were cultured using 


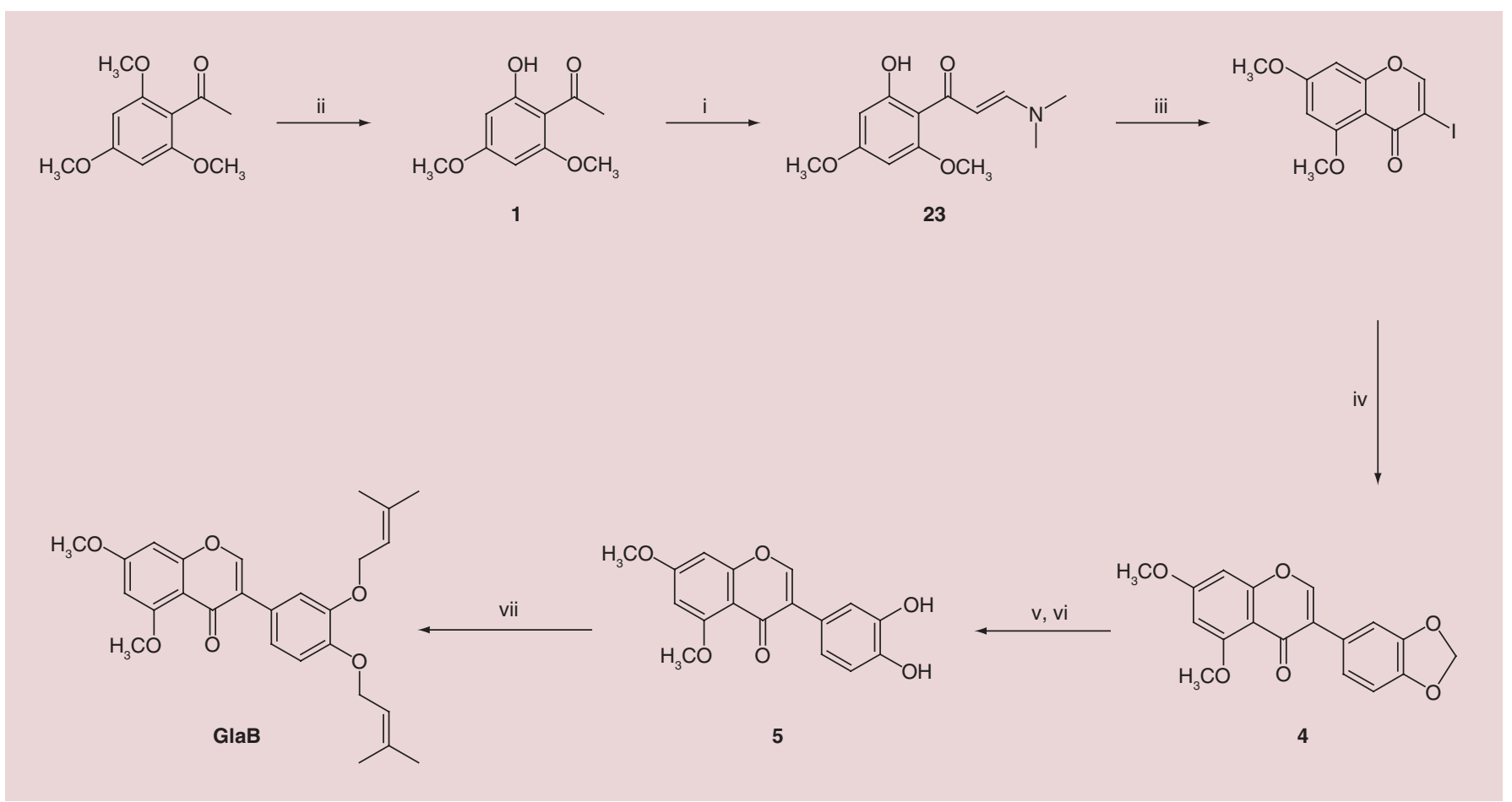

Figure 1. Synthesis of Glabrescione B. Reagents and conditions: (i) boron tribromide, dry dichloromethane, RT, 2 h; (ii) DMF-DMA, $95^{\circ} \mathrm{C}, 3 \mathrm{~h}$; (iii) iodine, methanol, RT, 1 h; (iv) 3,4-(methylenedioxy)-phenylboronic acid, PdEnCat ${ }^{\mathrm{TM}} 40$, sodium carbonate, DME/ $\mathrm{H}_{2} \mathrm{O}$ $1: 1$ (v/v), $45^{\circ} \mathrm{C}, 2 \mathrm{~h}$; (v) lead tetracetate, benzene dry, $80^{\circ} \mathrm{C}$, overnight; (vi) acetic acid, $\mathrm{THF} / \mathrm{H}_{2} \mathrm{O}(5: 1 \mathrm{v} / \mathrm{v}), \mathrm{RT}, 1 \mathrm{~h}$; (vii) 3,3-dimethylallyl bromide, potassium carbonate, acetone, reflux, $72 \mathrm{~h}$.

RT: Room temperature.

serum-free complete media (described in Supplementary materials) supplemented with B27 (Life Technologies, UK, 17504044) and N2 (Life Technologies, 17502048). Growth factors EGF (Peprotech, UK, 315-09-500) and FGF-2 (Peprotech, 100-18B-500) $(10 \mathrm{ng} / \mathrm{ml}$ ), as well as laminin (Sigma, L2020, $1 \mu \mathrm{g} /$ $\mathrm{ml}$ ), were added freshly before cell split. Cells were routinely grown to confluence and split typically twice per week after dissociation with Accutase solution (Sigma, A6964) and centrifugation. Differentiation of G7 cells was performed as described previously by Pollard and collaborators [35]. After reaching 70\% confluency, G7 cells were washed with PBS and replaced with media containing bone morphogenetic protein (BMP) 4 (Peprotech $120-05$ ET-10, $10 \mathrm{ng} / \mathrm{ml}$ ), but no EGF or FGF-2. Differentiation media, containing BMP, was replaced every 7 days throughout the time course and supplemented with fresh BMP at 4 days.

\section{Cytotoxicity studies in vitro}

Cells seeded in 96-well plates were incubated with GlaB or NC-GlaB $(200 \mu$ f final volume in complete media) for 48, 72 and $96 \mathrm{~h}$. Subsequently, the media was removed and replaced with $120 \mu \mathrm{l}$ of MTT solution $(0.5 \mathrm{mg} / \mathrm{ml})$. Cells were incubated for $3 \mathrm{~h}$ in normal culture conditions, after which the formazan crystals were dissolved in DMSO $(200 \mu \mathrm{l})$ and sample absorbance at $570 \mathrm{~nm}$ was measured in a FLUO star OPTIMA plate reader (BMG Labtech, UK). The results, expressed as the percentage cell survival (mean $\pm \mathrm{SD}$ ), were calculated using the following equation: $\%$ cell survival $=($ A570 $\mathrm{nm}$ of treated cells $/ \mathrm{A} 570 \mathrm{~nm}$ of untreated control cells) $\times 100$.

\section{Cell cycle analysis by flow cytometry}

The percentage of cells in each phase of the cell cycle was determined by flow cytometry. Briefly, cells seeded in 24-well plates $\left(5 \times 10^{4}\right)$ were treated with $5 \mu \mathrm{M}$ of GlaB, NC-GlaB or equivalent concentrations of empty NCs. After treatment, cells were washed with PBS, trypsinized and transferred into BD flow cytometer tubes. After centrifugation at $500 \times g$ for $5 \mathrm{~min}$ (for trypsin removal), cells were fixed by incubation with $70 \%$ cold ethanol for $1 \mathrm{~h}$. After washing with PBS (to remove traces of ethanol), fixed cells were treated with $50 \mu \mathrm{l}$ of RNase A in PBS $\left(100 \mu \mathrm{g} / \mathrm{ml}, 10 \mathrm{~min}\right.$ at $\left.37^{\circ} \mathrm{C}\right)$, to ensure that RNA labeling does not interfere with the results. Subsequently, cells were stained for $30 \mathrm{~min}$ at $37^{\circ} \mathrm{C}$ in the dark with $400 \mu \mathrm{l}$ of propidium iodide (PI) solution ( $40 \mu \mathrm{g} / \mathrm{ml}$ of PI in PBS). PI fluorescence was then measured in the FL-2 channel using a BD FACS Calibur flow cytometer (BD Bioscience, CA, USA). 
For each condition, 10,000 events were gated and fluorescence was analyzed using the FlowJo software. Results were expressed as averages of percentage cell populations in each phase of the cell cycle $\pm S D(n=3)$.

\section{Western blot analysis}

SKOV3, PANC1, GL261, G7 and IENS GMB cells were cultured on 6-well plates and incubated with culture media for $24 \mathrm{~h}$. PANC1 and SKOV3 cells were cultured on 6-well plates and incubated with $5 \mu \mathrm{M}$ GlaB for 24 or $48 \mathrm{~h}$. At the end of the treatment, cells were rinsed twice with ice-cold PBS, incubated with RIPA buffer (radioimmunoprecipitation Assay buffer, $1 \%$ triton X-100, $0.5 \%$ sodium deoxycholate, $0.1 \%$ SDS, $50 \mathrm{mM}$ Tris- $\mathrm{HCl}$ and $0.15 \mathrm{M} \mathrm{NaCl}, \mathrm{pH}$ 8) containing protease inhibitor (Complete Ultra, Roche Diagnostics $\mathrm{GmbH}$, Germany). Cells were scrapped out and the collected lysates were kept on ice for additional $30 \mathrm{~min}$ with intermittent vortexing every $10 \mathrm{~min}$. Lysate solutions were centrifuged at $17,949 \times g$ for $30 \mathrm{~min}$, and the supernatants containing cell proteins were collected. The concentration of the isolated proteins was determined using BCA Protein Assay kits (Pierce BCA protein assay kit, Thermal Scientific, UK). About $100-200 \mu \mathrm{g}$ of the protein was resolved in $8 \%$ SDS-PAGE and electrophoretically transferred to Hybond ECL nitrocellulose membranes (GE Healthcare, UK). Membranes were blocked in 3\% bovine serum albumin (Sigma-Aldrich, UK) at room temperature for $1 \mathrm{~h}$. Membranes were then incubated with the primary antibodies against Gli1 (rabbit antimouse antibody, PA5-23411; rabbit antihuman antibody, PA5-28384; Thermofisher Scientific, UK) at 1:1000 dilution or GAPDH (\#14C10, Cell Signaling Technology, CA, USA) at 1:5000 dilution over night at $4^{\circ} \mathrm{C}$. Membranes were washed three-times with Trisbuffered saline containing $0.1 \%$ Tween ${ }^{\circledR} 20$ (TBS-T) and then incubated with secondary antibodies, horseradish peroxidase-linked goat antirabbit antibodies (\#7074, Cell Signaling Technology) at 1:3000 dilution for $2 \mathrm{~h}$ at room temperature. The protein bands were detected using chemiluminescent kits (Immun-Star ${ }^{\mathrm{TM}}$ Chemiluminescent Kit, BioRad, UK) and imaged by the ChemiDoc MP imaging system and Image Lab software (BioRad). GAPDH was used as an internal protein control. Values for Glil were normalized to the total GAPDH and then to untreated IENS, in the case of treatment to untreated PANC1 and SKOV3.

\section{Radiolabeling of NCs}

Radiolabeling of NC-PEG-DTPA-GlaB

The radioactive probe ${ }^{111} \mathrm{InCl}_{3}$ was purchased from Mallinckrodt Pharmaceuticals (The Netherlands) as an aqueous solution in $0.5 \mathrm{M} \mathrm{HCl}$ and used with- out further purification. To radiolabel the $\mathrm{NC}$ with indium-111, NCs were prepared in water as described in the previous section except that PLGA-PEGDTPA was included at $10 \%(\mathrm{w} / \mathrm{w})$ of total polymer content and concentrated 28-times using rotavap, so that the final drug and polymer concentrations are 1.22 and $71.43 \mathrm{mg} / \mathrm{ml}$, respectively. The NC suspension $(700 \mu \mathrm{l})$ was incubated with $2 \mathrm{M}$ ammonium acetate (one-ninth of the reaction volume, $\mathrm{pH}$ 5.5), to which $10 \mathrm{MBq}$ of ${ }^{111} \mathrm{InCl}_{3}$ was added per injection dose for $\gamma$ scintigraphy. The reaction was kept at room temperature for $30 \mathrm{~min}$ with intermittent vortexing every $10 \mathrm{~min}$. Upon completion, the radiolabeling reaction was quenched by the addition of $0.1 \mathrm{M}$ EDTA chelating solution (one-twentieth of the reaction volume). ${ }^{111} \mathrm{InCl}_{3}$ alone and NCs without DTPA incorporation were also subjected to the same conditions of the labeling reaction as a control.

\section{Radiolabeling efficiency \& serum stability studies}

To evaluate the radiolabeling efficiency, the labeled NC- ${ }^{111}$ In was spotted on the TLC strips, which were developed in $0.1 \mathrm{M}$ ammonium acetate containing 25 mM EDTA as a mobile phase. Strips were allowed to dry before being developed and counted quantitatively using a cyclone phosphor detector (Packard Biosciences, UK). The NC- ${ }^{111}$ In was passed through PD-10 column before injecting into animals to exchange the ammonium acetate buffer ( $\mathrm{pH} 5.5$ ) with PBS ( $\mathrm{pH} 7.4$ ) and to ensure that no free ${ }^{111}$ In-EDTA was present in the injected dose. The sample was collected from the column and the radiolabeling efficiency was examined immediately after the collection. As a result, the sample was further diluted two-times to three-times compared with the original sample. Final drug concentration after filtration was $1.22 \mathrm{mg} / \mathrm{ml}$. To determine the stability of the radiolabeled NC-111 In, $20 \mu \mathrm{l}$ of the sample was incubated with $20 \mu \mathrm{l}$ of serum and $20 \mu \mathrm{l}$ of PBS at $37^{\circ} \mathrm{C}$. At $24 \mathrm{~h}, 2 \mu \mathrm{l}$ of the incubated samples was spotted to the TLC strips, which were developed and quantified as described above. Free ${ }^{111}$ In-EDTA was detected at the solvent front while radiolabeled NC was retained at the application point. Indium-labeled NC without DTPA incorporation was included as a control.

\section{Tumor xenograft animal model studies}

All animal experiments were performed in compliance with the UK Home Office Code of Practice for the Housing and Care of Animals Used in Scientific Procedures. Six- to eight-week-old female SCID/Beige mice (Harlan Laboratories, UK) were caged in individually vented cages in groups of four with free access to food and water. A temperature of $19-22^{\circ} \mathrm{C}$ was 
maintained, with a relative humidity of $45-65 \%$, and a $12 \mathrm{~h}$ light/dark cycle. Established human pancreatic PANC1 and PANC0403 xenograft tumor models were applied. Mice were inoculated subcutaneously with $1 \times 10^{6}$ cells in $100 \mu \mathrm{l}$ on either flanks subcutaneously.

\section{Tissue biodistribution by $\gamma$ scintigraphy}

Forty days after tumor inoculation, pancreatic-tumorbearing SCID/Beige mice ( $\mathrm{n}=2$ per time point) were injected intravenously, via tail vein, with $200 \mu \mathrm{l}$ of NCs at a dose of $115 \mathrm{mg} / \mathrm{kg}$ of polymer and $18.5 \mathrm{mg} /$ $\mathrm{kg}$ of drug containing approximately $1 \mathrm{MBq}$ of radioactivity $(2.3 \mathrm{mg}$ of polymer, $\sim 370 \mu \mathrm{g}$ of drug, $1 \mathrm{MBq}$ per mouse). Animals were sacrificed after $30 \mathrm{~min}$ or $24 \mathrm{~h}$. The tumors and major organs (brain, lung, liver, spleen, kidney and heart) were collected, weighed, and the ${ }^{111}$ In activity in the collected tissues was quantified using an automated $\gamma$ counter (LKB Wallac 1282 Compugamma, Perkin Elmer, UK). A portion of the radiolabeled NCs was also analyzed as a reference. The $\gamma$ counter corrected for physical radioisotope decay. Radioactivity readings (c.p.m.) were plotted as a \% $\mathrm{ID} /$ organ or as a $\% \mathrm{ID} / \mathrm{g}$ of tissue.

\section{Organ toxicity evaluation}

Twenty-eight days after tumor inoculation, pancreatictumor-bearing SCID/Beige mice $(n=6)$ were injected, via tail vein, with $200 \mu \mathrm{l}$ of the NCs at a dose of 78 $\mathrm{mg} / \mathrm{kg}$ of polymer and $12.5 \mathrm{mg} / \mathrm{kg}$ of drug $(\sim 1.56 \mathrm{mg}$ of polymer and $\sim 250 \mu \mathrm{g}$ of drug per mouse) once a week for 3 weeks. At the experiment end point, the mice were sacrificed and the major organs (liver, lung, tumor, heart, kidney and spleen) were fixed in 10\% neutral buffer formalin as $5 \mathrm{~mm}^{2}$ pieces. The organs were then paraffin-embedded and sectioned for hematoxylin and eosin according to the standard histological protocols at the Royal Veterinary College. The stained sections were analyzed with a Leica DM 1000 LED Microscope (Leica Microsystems, UK) coupled with charge-coupled device (CDD) digital camera (Qimaging, UK).

\section{Results}

\section{Synthesis of GlaB}

The synthesis of the GlaB (Figure 1) began from commercially available $2^{\prime}, 4^{\prime}, 6^{\prime}$-trimethoxyacetophenone. The O-demethylation was selectively obtained in position 2 by treatment of $2^{\prime}, 4^{\prime}, 6^{\prime}$-trimethoxyacetophenone with boron tribromide $\left(\mathrm{BBr}_{3}\right)$ to give 2'-hydroxy$4^{\prime}, 6^{\prime}$-dimethoxyacetophenone $\mathbf{1}$. Compound $\mathbf{1}$ was subsequently treated with $\mathrm{N}, \mathrm{N}$-dimethylformamide dimethyl acetal to form the enamino ketone $\mathbf{2}$, which, on stirring in methanol with excess iodine, underwent tandem cyclization and iodination to afford 3-iodo-
5,7-dimethoxy-4H-chromen-4-one 3 [36]. Cross-coupling of 3 with 3,4-(methylenedioxy)-phenylboronic acid in the presence of $\mathrm{Pd} \mathrm{EnCat}^{\mathrm{TM}} 40$ catalyzed Suzuki reaction gave 3-( $3^{\prime}, 4^{\prime}$-methylendioxyphenyl)5,7-dimethoxy-4H-chromen-4-one 4. Notably, the Suzuki-Miyaura reaction was accomplished by the use of polyurea-encapsulated palladium (Pd EnCat ${ }^{\mathrm{TM}} 40$ ), a robust and recyclable catalyst which was designed in 2002 [37] and used under mild conditions [38]. The methylene acetal in $\mathbf{4}$ was oxidatively removed by treatment with $\mathrm{Pb}(\mathrm{OAc})_{4}$ allowing the clean formation of acetoxy acetal, which was smoothly hydrolyzed to provide the desired catechol 5 [39]. The final step was the prenylation of compound $\mathbf{5}$, which was accomplished by treatment with 3,3-dimethylallyl bromide and $\mathrm{K}_{2} \mathrm{CO}_{3}$ under refluxing acetone to yield $\mathrm{GlaB}$ [40]. The spectral data of GlaB obtained by synthesis were identical to those found in the natural product. The overall reaction yield was $7 \%$.

\section{Formulation \& physico-chemical \\ characterization of NCs}

The preparation of non-PEG-containing NC (NC$\mathrm{GlaB}$ ) is described in detail in the 'Materials \& methods' section. PEG-containing NCs (NC-PEG) were also prepared, due to their prolonged blood circulation time facilitated by PEG. All formulations were prepared using the nanoprecipitation method (Figure 2). The purified formulations were then characterized for their hydrodynamic diameter, PDI and $\zeta$ potential, immediately after purification and over 28 days storage at $4^{\circ} \mathrm{C}$ (Table 1 \& Supplementary Table 1). Castor oil was selected as the core material due to its good oil solubilization ability of the drug $\left(27 \mu \mathrm{g} / \mu \mathrm{l}\right.$ at $\left.37^{\circ} \mathrm{C}\right)$. Importantly, efficient drug encapsulation ( $90 \%)$ was achieved for both NC-GlaB and NC-PEG-GlaB (Table 1 \& Supplementary Table 1). In contrast to the extremely poor aqueous solubility of GlaB [21], NCGlaB were well dispersed and formed a homogeneous suspension in aqueous media with PDI values below 0.2 and an average hydrodynamic diameter of approximately $160 \mathrm{~nm}$. All NC formulations were found to be stable over the 28-day storage period, with no significant changes in size, PDI or $\zeta$ potential observed over time. No apparent change in color or phase separation was observed in any of the formulations.

\section{In vitro stability of the NCs}

To determine the in vitro stability of GlaB in the NC formulation, drug release from NC-PEG-GlaB was assessed over $24 \mathrm{~h}$ by the dialysis method, in the presence or absence of FBS. The dialysate used was PBS $\mathrm{pH} 7.4$ containing $10 \% \mathrm{w} / \mathrm{v}$ Tween ${ }^{\circledR} 80$ to maintain GlaB solubility in aqueous media. As shown in 


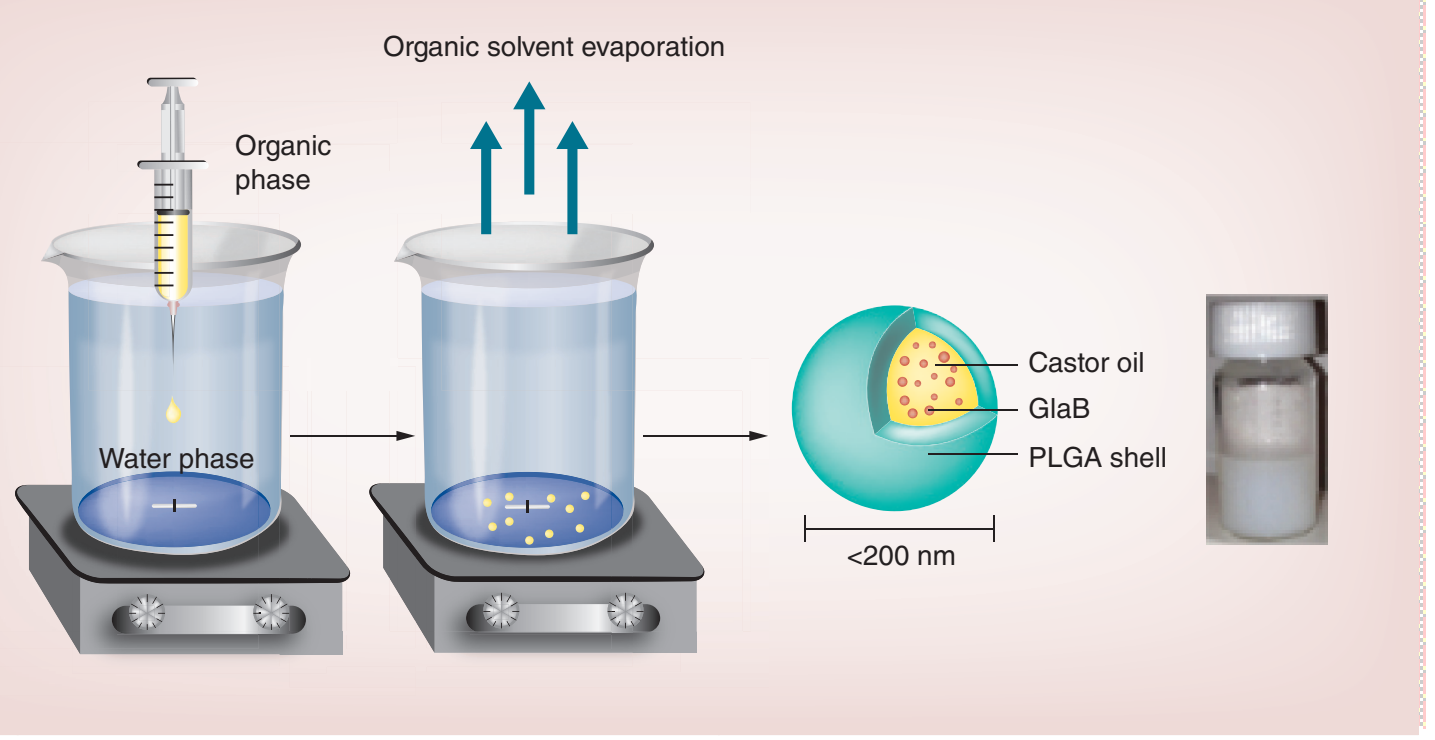

Figure 2. Schematic representation of the formulation method of the oil-cored nanocapsules. The organic phase, composed of polymer, oil, lipophilic surfactant and the drug dissolved in a water-miscible solvent, was added dropwise to an aqueous phase containing a hydrophilic surfactant. Formation of NCs takes place by solvent diffusion and polymer precipitation. Finally, the solvent was removed forming an aqueous dispersion of the NC. The average diameter of the NCs is approximately $160 \mathrm{~nm}$. NC: Nanocapsule.

Figure 3, drug release from the NC formulation did not exceed $20 \%$ over the course of $24 \mathrm{~h}$, a value that was not altered by the presence of $50 \%$ FBS.

\section{In vitro cytotoxicity of GlaB}

The MTT assay was performed in order to estimate the toxicity of free or NC-formulated GlaB. Two dif- ferent types of cell lines were selected for this study: non-stem cancer cells that contain a small CSC subpopulation (PANC1, human pancreatic carcinoma; SKOV3, human ovary adenocarcinoma; and GL261, murine glioma) [41-43] and pure glioblastoma-derived neural stem cells (GNS; patient-derived G7 human and engineered Ink4a/ARF, EGFRvIII overexpressed

\section{Table 1. Shelf-life stability of oil-cored nanocapsules prepared using PLGA as polymer.}

\begin{tabular}{|c|c|c|c|c|c|c|}
\hline Sample & Day & $\begin{array}{l}\text { Hydrodynamic } \\
\text { diameter }{ }^{\dagger, \neq}\end{array}$ & $\mathrm{PDI}^{t, \neq}$ & $\begin{array}{l}\zeta \text { potential } \\
(\mathrm{mV})^{ \pm, \S}\end{array}$ & $\begin{array}{l}\text { Encapsulation } \\
\text { efficiency }(\% \mathrm{EE})^{ \pm, \pi}\end{array}$ & $\begin{array}{l}\text { Loading efficiency } \\
(\% \text { LE })^{ \pm, \#}\end{array}$ \\
\hline \multirow[t]{5}{*}{ NC } & 1 & $164.0 \pm 1.9$ & $0.19 \pm 0.01$ & $-54.0 \pm 1.8$ & \multirow[t]{5}{*}{-} & \multirow[t]{5}{*}{-} \\
\hline & 7 & $162.4 \pm 1.2$ & $0.18 \pm 0.01$ & $-59.3 \pm 0.2$ & & \\
\hline & 14 & $151.1 \pm 0.8$ & $0.14 \pm 0.01$ & $-67.8 \pm 1.6$ & & \\
\hline & 21 & $155.6 \pm 1.5$ & $0.17 \pm 0.02$ & $-56.2 \pm 0.6$ & & \\
\hline & 28 & $166.1 \pm 1.3$ & $0.21 \pm 0.01$ & $-57.6 \pm 0.7$ & & \\
\hline \multirow[t]{5}{*}{ NC-GlaB } & 1 & $159.4 \pm 1.0$ & $0.17 \pm 0.01$ & $-39.8 \pm 0.5$ & \multirow[t]{5}{*}{$85 \pm 6.1$} & \multirow[t]{5}{*}{$27.5 \pm 1.9$} \\
\hline & 7 & $155.9 \pm 0.4$ & $0.12 \pm 0.02$ & $-47.0 \pm 0.6$ & & \\
\hline & 14 & $148.6 \pm 1.0$ & $0.13 \pm 0.02$ & $-58.0 \pm 1.8$ & & \\
\hline & 21 & $154.8 \pm 0.9$ & $0.14 \pm 0.02$ & $-49.7 \pm 1.5$ & & \\
\hline & 28 & $154.3 \pm 1.1$ & $0.14 \pm 0.01$ & $-46.7 \pm 1.7$ & & \\
\hline \multicolumn{7}{|c|}{$\begin{array}{l}\text { `Measured with dynamic light scattering. } \\
\text { "Expressed as mean } \pm \text { SD }(n=3) \text {. } \\
\text { \$Analyzed with electrophoretic light scattering using } 10 \mathrm{mM} \mathrm{NaCl} \text {. } \\
\text { "Calculated as percentage of initial drug added, which was determined by spectrophotometry. } \\
\text { "Calculated as mass of incorporated drug divided by the weight of polymer, which was determined by spectrophotometry. } \\
\text { GlaB: Glabrescione B; NC: Nanocapsule; NC-GlaB: GlaB-loaded oil-cored polymeric nanocapsule; PDI: Polydispersity index; SD: Standard } \\
\text { deviation. }\end{array}$} \\
\hline
\end{tabular}


IENS murine) [31]. It is hypothesized that the GNS cell lines will be more sensitive to $\mathrm{GlaB}$ as they consist entirely of CSCs and therefore have a stronger dependence on the Hh pathway. Indeed, western blot quantification of Gli1 protein expression, a downstream effector in the Hh pathway, showed higher Gli1 protein levels in pure CSCs (IENS and G7), compared with non-stem cancer cells (PANC1, SKOV3 and GL261) (Supplementary Figure 1).

As demonstrated in Figure 4A \& Supplementary Figure 2, a dose-dependent and time-dependent reduction in cell viability was observed in both treatment conditions (NC-GlaB and free GlaB). Incubation for $96 \mathrm{~h}$ with $5 \mu \mathrm{M}$ of free GlaB/NC-GlaB resulted in a significant reduction in cell viability in IENS ( 27\%/14\% cell viability; $\mathrm{p}<0.05)$ and G7 $(\sim 20 \% / 13 \%$; $\mathrm{p}<0.001 / \mathrm{p}<0.01)$ cells, while a smaller decrease was seen in GL261 ( 67\%/84\%; p > 0.05) or PANC1 ( 36\%/48\%; p > 0.05) cells. Light microscopy images obtained during treatment confirmed the dose-dependent cell killing effect verified with the MTT assay. Morphological changes, namely smaller and more round, were observed during incubation with free GlaB or NC-GlaB (Figure 4C). Cells treated with empty NCs, at equivalent concentrations to those used in NC-GlaB, showed normal cell morphology except at very high concentration, in which slight but significant toxicity was detected (Supplementary Figure 3).

$\mathrm{IC}_{50}$, the drug amount required to achieve $50 \%$ cell kill, was estimated in G7 and PANC1 cells. The values obtained following $96 \mathrm{~h}$ treatment with free $\mathrm{GlaB} /$ NC-GlaB were $0.29 \mu \mathrm{M} / 0.71 \mu \mathrm{M}$ (G7) and 1.62 $\mu \mathrm{M} / 1.49 \mu \mathrm{M}$ (PANC1) (Figure 4B). The toxicity of NC-PEG-GlaB was also tested, to assess whether the incorporation of PEG into the NCs has any effect on cell viability. Comparable results were obtained at 96 $\mathrm{h}$ with $5 \mu \mathrm{M}$ GlaB, for NC-PEG-GlaB $(\sim 74 \%)$ and NC-GlaB ( 86\%) (Supplementary Figure 4).

\section{GlaB effect on cell cycle}

Having shown that free or NC-formulated GlaB has an effect on the viability of GNS cells and, to a lesser extent, on non-stem cancer cells, experiments were performed to determine whether the effect could be due to alterations in the cell cycle mechanism. As shown in Figure 5 (left panel) and Supplementary Figure 5, a steady increase in cell cycle arrest at G2 phase was detected after IENS treatment with $5 \mu \mathrm{M}$ of NC-GlaB at 24 and $48 \mathrm{~h}(\sim 25.3$ and $30.2 \%$ of cells in G2, respectively), when compared with untreated cells ( 15.0 and 5.3\%). Similar values were obtained for treatment with $5 \mu \mathrm{M}$ of free $\mathrm{GlaB}$ ( 26.7 and 24.8\%). In the case of the PANC1 cells (Figure 5, right panel \& Supplementary Figure 4), a

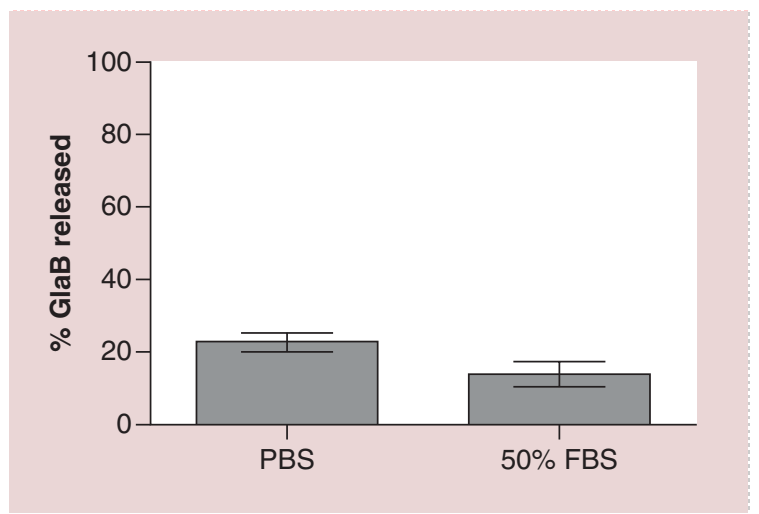

Figure 3. Release profile of glabrescione $B$ from nanocapsules. NC-PEG-GlaB were dialyzed for $24 \mathrm{~h}$ against $10 \% \mathrm{w} / \mathrm{v}$ Tween ${ }^{\circledR} 80$ in PBS, pH 7.4, in the presence or absence of $50 \%$ FBS. Drug concentration inside the dialysis bag was assessed by measuring the absorbance at $258 \mathrm{~nm}$. Results are expressed as means \pm standard deviation $(n=3)$.

FBS: Fetal bovine serum; NC-PEG-GlaB: PEG-containing nanocapsules loaded with GlaB; GlaB: Glabrescione B; PBS: Phosphate-buffered saline.

shift in cell cycle distribution from G1 to $S$ phase was observed with GlaB treatments at 24 and $48 \mathrm{~h}(\sim 35.5$ and $37.9 \%$ of cells in the $S$ phase, respectively), compared with untreated cells ( 25.2 and $24.6 \%)$. A significant shift in the cell cycle profile was not detected in PANC1 cells incubated with NC-GlaB.

\section{Effect of GlaB treatment on Gli1 protein} expression, analyzed by western blot

Since not enough protein could be obtained from IENS or G7 cells treated with GlaB, due to high sensitivity to the drug, PANC1 and SKOV3 were selected to further clarify the influence of GlaB incubation on Gli1 protein levels. In this regard, decreased Gli1 expression was detected in the cells after incubation with $5 \mu \mathrm{M}$ GlaB for $24 \mathrm{~h}(\sim 73.3 \%$ relative expression for SKOV3, $88.1 \%$ for PANC1) or 48 h ( $33.6 \%$ for SKOV3, $44.6 \%$ for PANC1), compared with control untreated cells $(100 \%)$ (Supplementary Figure 6). These results suggest that $\mathrm{GlaB}$ treatment suppresses the expression of Gli1.

\section{Effect of GlaB treatment in differentiated CSCs} In order to confirm that the activity of $\mathrm{GlaB}$ is $\mathrm{Hh}$ dependent (and thus connected to stemness), the differentiation of G7 cells into astrocytes was promoted by incubating these cells with BMP4, as shown previously by Carén $e t$ al. [35]. It is expected that differentiated G7 cells are less dependent on Hh pathway and therefore less sensitive to GlaB. Indeed, as shown in Figure 6A \& B, and opposed to what was observed with pristine G7 cells, no significant toxicity was seen in differentiated G7 cells incubated with free GlaB for 

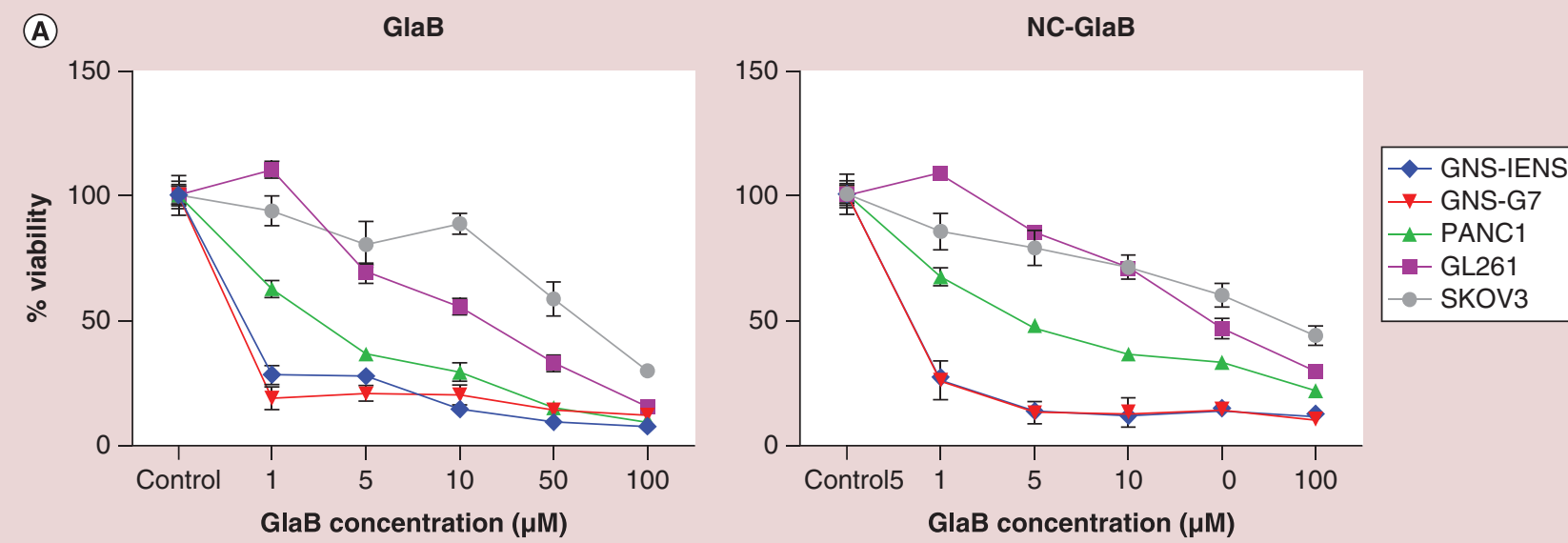

(B)

GNS-G7

PANC1
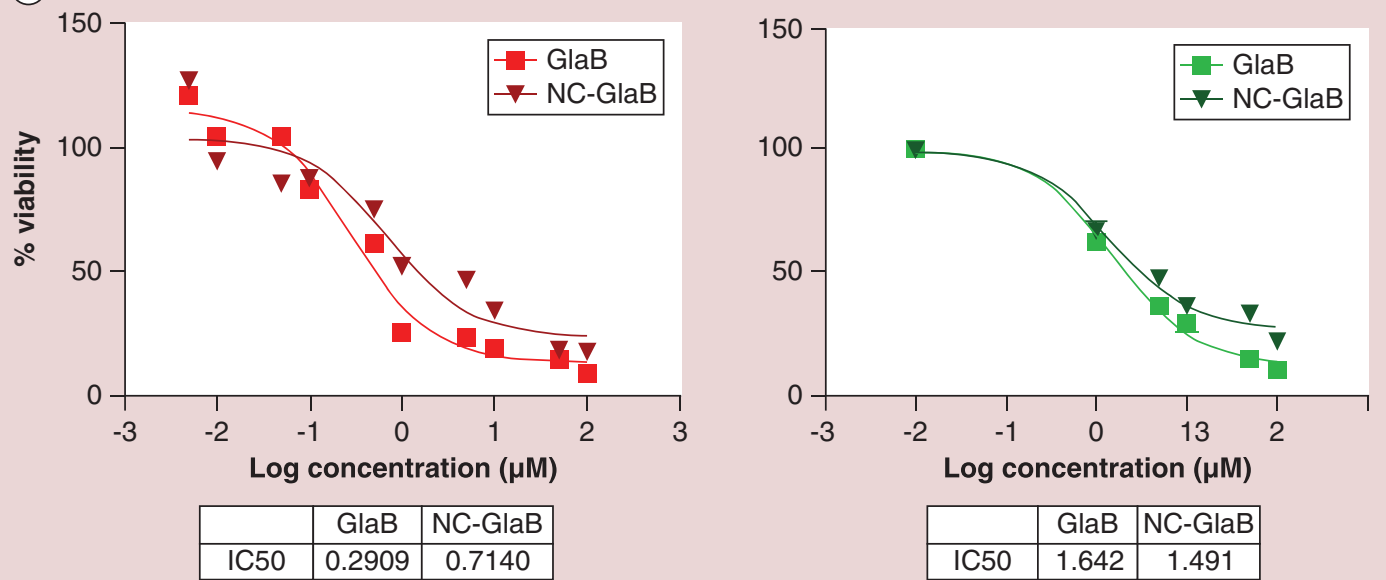

(C)

\begin{tabular}{|c|c|c|}
\hline & GlaB & NC-GlaB \\
\hline IC50 & 0.2909 & 0.7140 \\
\hline
\end{tabular}

$5 \mu \mathrm{M}$
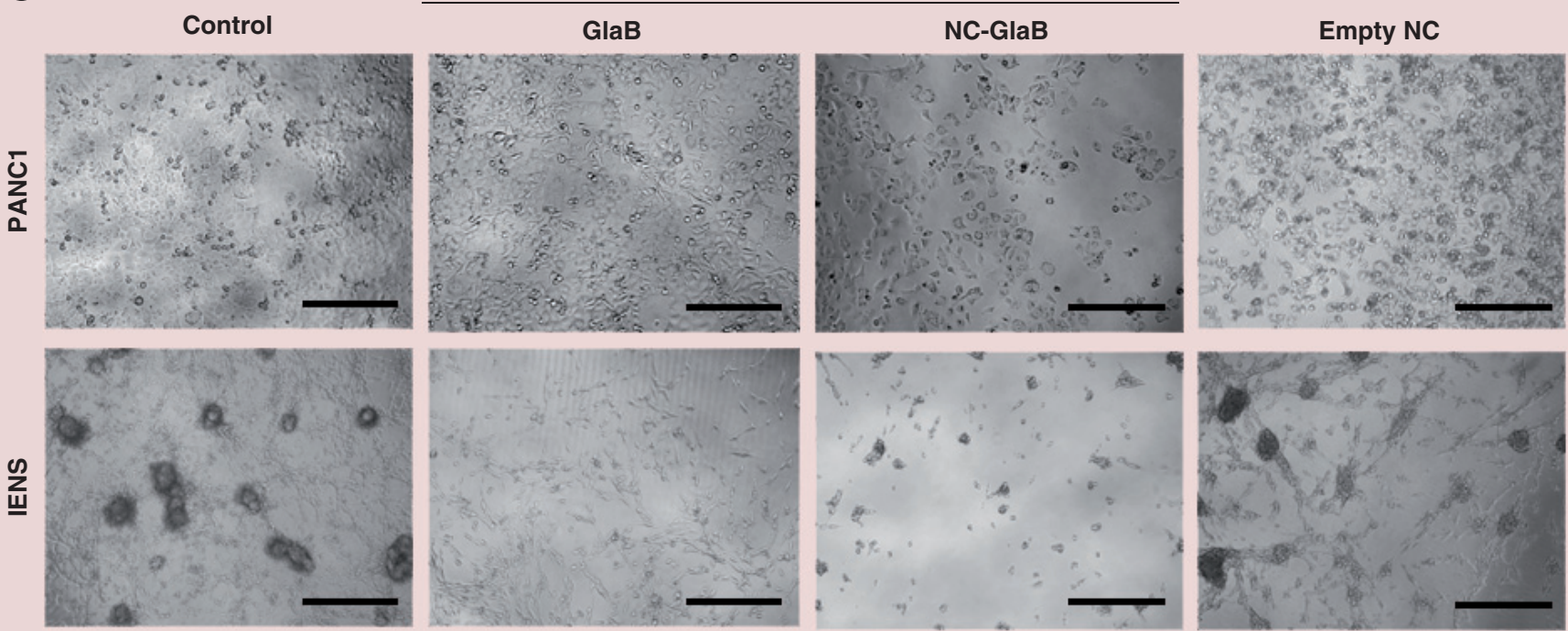

with GlaB or NC-GlaB for $96 \mathrm{~h}$ at increasing drug concentrations (1-100 $\mu \mathrm{M})$. (A) Cell viability, expressed as a percentage of control untreated cells, was determined by MTT assay after $96 \mathrm{~h}$ incubation with free GlaB (left) or NC-GlaB (right) treatments. (B) GlaB and NC-GlaB dose-response curve and IC $_{50}$ values for GNS-G7 (left) and PANC1 cells (right) after $96 \mathrm{~h}$ treatment with GlaB or NC-GlaB at increasing drug concentrations (from $0.05-1$ to $100 \mu \mathrm{M}$ ). Results are expressed as mean \pm SD $(n=5)$. (C) Microscopic observation of cells at $96 \mathrm{~h}$ after treatment with GlaB, NC-GlaB or empty NC, at a final concentration of $5 \mu \mathrm{M}$ GlaB. Scale bar corresponds to $150 \mu \mathrm{m}$. GlaB: Glabrescione B; NC: Nanocapsule; NC-GlaB: GlaB-loaded oil-cored polymeric nanocapsule; SD: Standard deviation. 


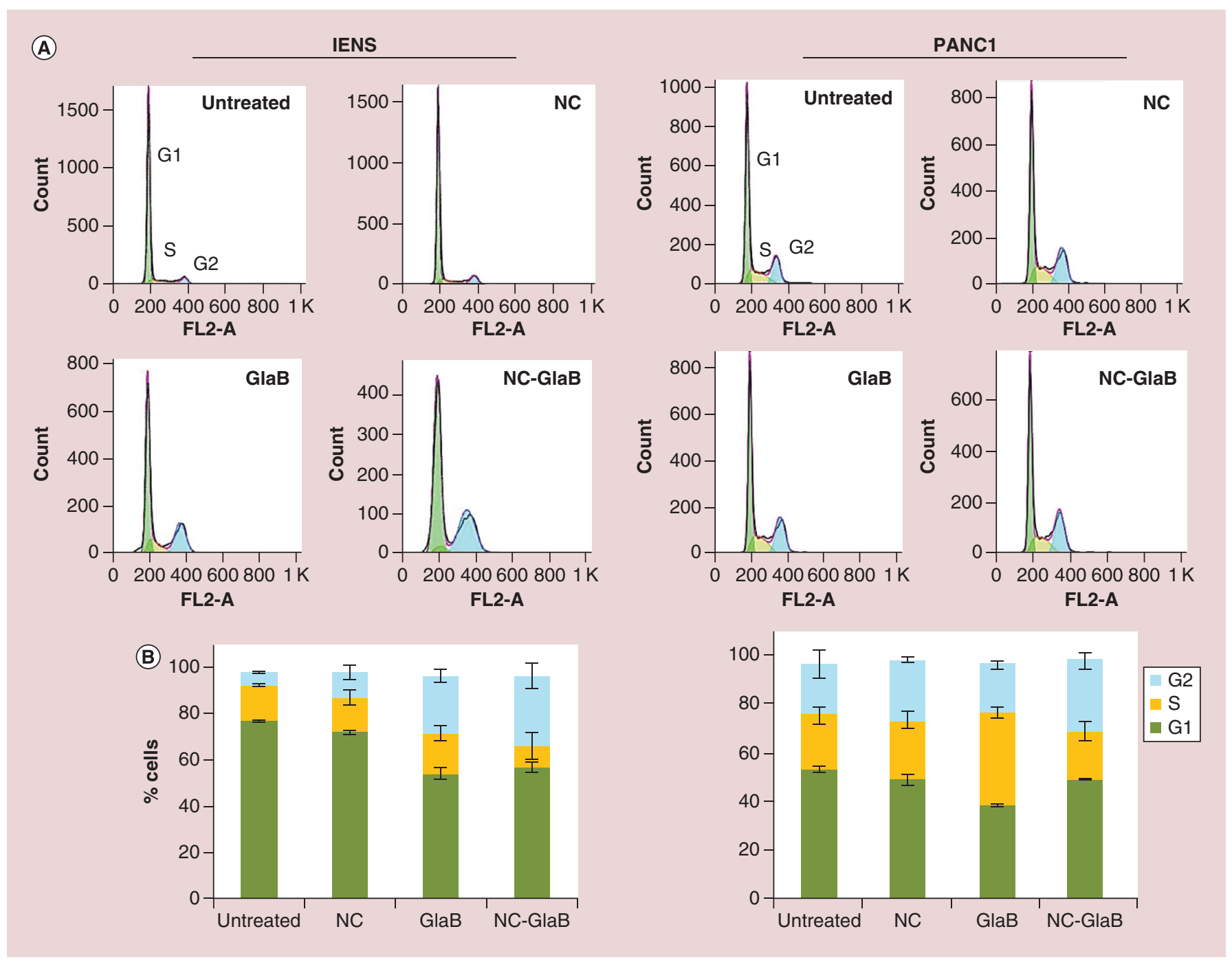

Figure 5. Cell cycle analysis in cultured IENS and PANC1 cells after treatment with glabrescione B. (A) Representative histograms showing the cell cycle distribution and (B) relative changes in the percentage of cells in each cell cycle phase, following incubation for $48 \mathrm{~h}$ with $5 \mu \mathrm{M}$ GlaB. Results are expressed as mean \pm standard deviation $(n=3)$.

GlaB: Glabrescione B; NC: Nanocapsule; NC-GlaB: GlaB-loaded oil-cored polymeric nanocapsule.

the tested concentrations except the highest $(50 \mu \mathrm{M})$. This unexpected toxicity could be due to crystal formation at such high drug concentration. When incubated with NC-GlaB at all the tested concentrations, no significant cytotoxicity was observed in differentiated G7 cells (Figure 6A \& C; Supplementary Figure 7).

\section{Radiolabeling of NC-PEG-GlaB \& in vitro stability}

In order to perform in vivo biodistribution studies, radiolabeled NCs were prepared using the previously synthesized PLGA-NH-PEG-NH-DTPA at 10\% $(\mathrm{w} / \mathrm{w})$ of total polymer content. The presence of DTPA in the shell of the NCs is necessary for complexing ${ }^{111} \mathrm{In}$, a useful short-lived $\gamma$ emitter used in biodistribution studies. The radiolabeling efficiency, calculated as the percentage of bound ${ }^{111} \mathrm{In}$ of total added ${ }^{111} \mathrm{In}$, was tested using instant thin layer chromatography (TLC) technique after chelation of ${ }^{111} \mathrm{In}$. Only [ $\left.{ }^{111} \mathrm{In}\right]-$ EDTA or $\left[{ }^{111} \mathrm{In}\right]-\mathrm{DTPA}$ chelates migrated to the solvent front while the radiolabeled polymer remained at the application point. Approximately $90 \%$ of radiolabeling efficiency was achieved for NC-DTPA (Figure 7A). Buffer exchange from ammonium acetate to PBS was also carried out using gel filtration chromatography. By passing the NC suspension through PD10 size exclusion columns, unbound ${ }^{111}$ In was retained in the column and the eluted NC suspension (in PBS) was ready for injection to mice. Radiolabeled NCs were found to be stable in solution, with approximately 92 and $72 \%$ stability obtained after NC incubation in PBS or $50 \%$ FBS (respectively) at $37^{\circ} \mathrm{C}$ for $24 \mathrm{~h}$. 

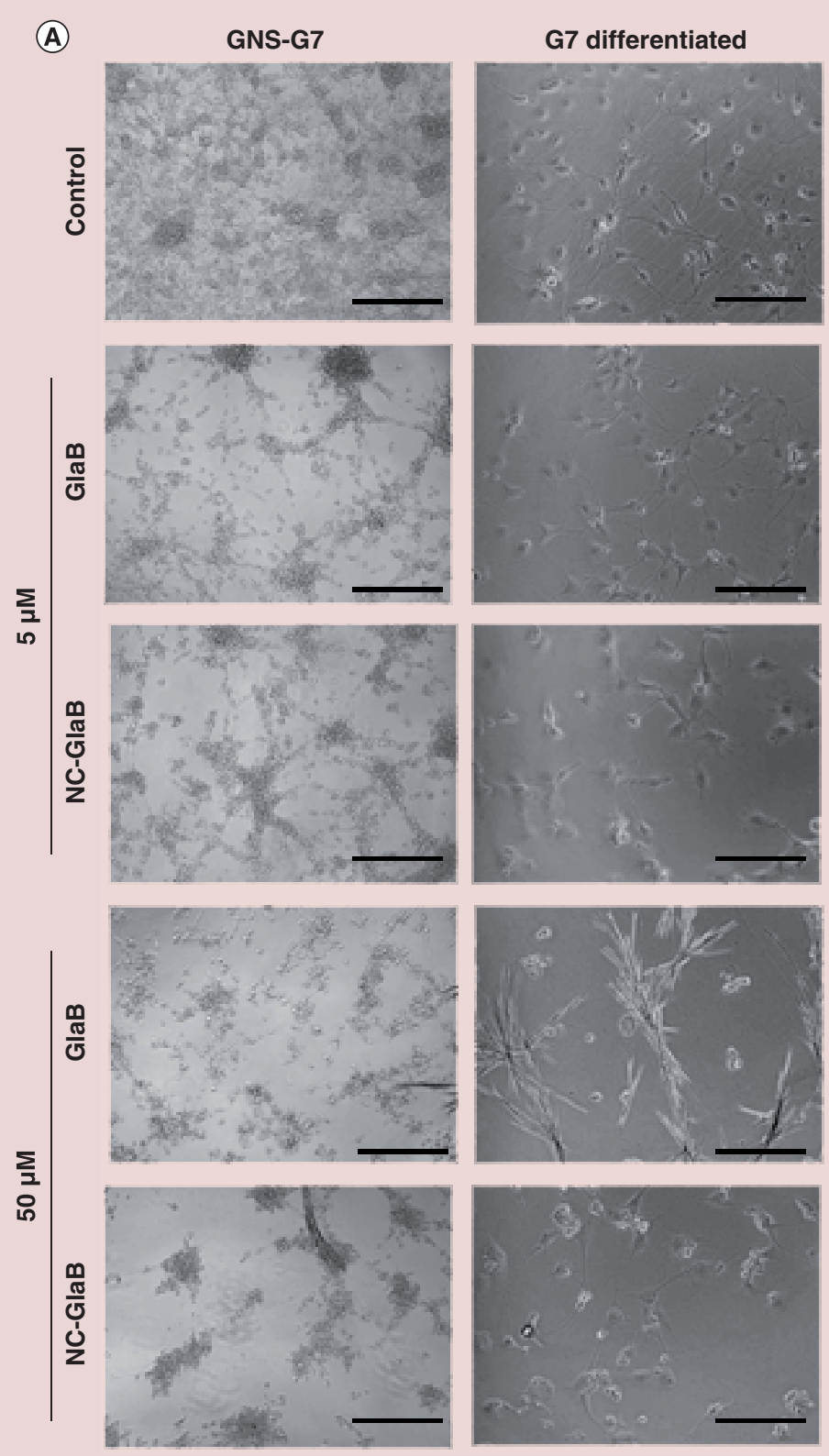

(B)

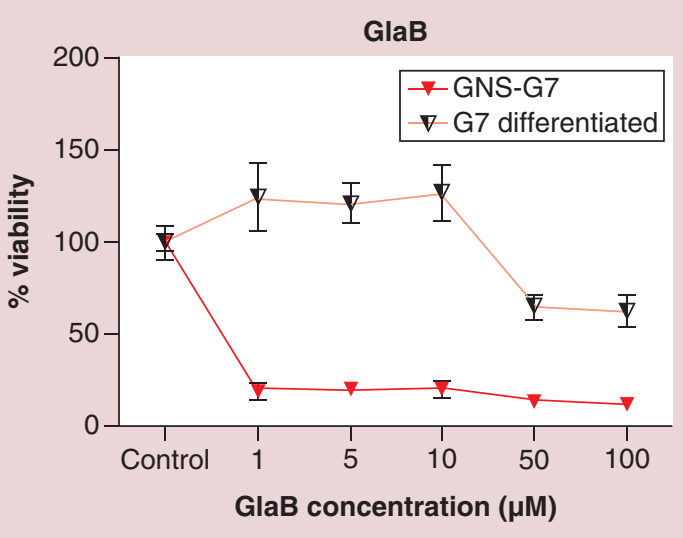

(C)

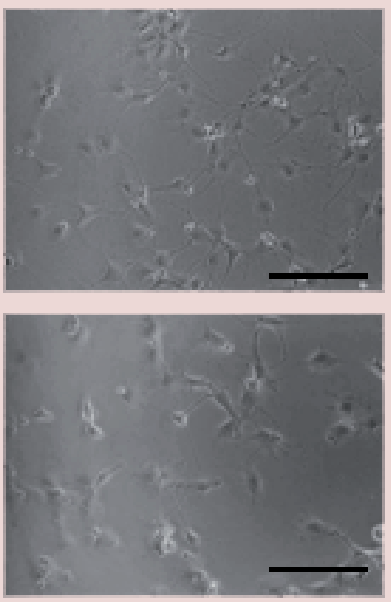

NC-GlaB
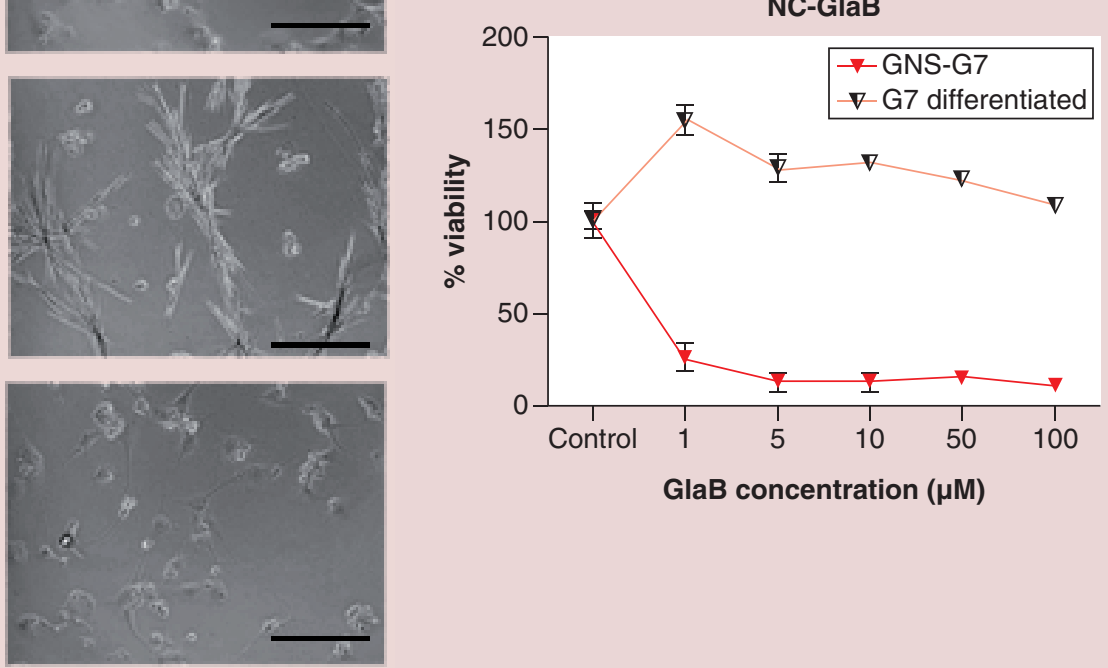

Figure 6. In vitro cytotoxicity of glabrescione B and glabrescione-B-loaded oil-cored polymeric nanocapsules in normal or differentiated $\mathrm{G7}$ cells. Cells were incubated with GlaB or NC-GlaB for $96 \mathrm{~h}$ at increasing drug concentrations (1-100 $\mu \mathrm{M})$.

(A) Microscopic observation of cells after treatment with GlaB or NC-GlaB for $96 \mathrm{~h}$ at 5 and $50 \mu \mathrm{M}$ of GlaB (scale bar corresponds to $150 \mu \mathrm{m})$. Cell viability after $96 \mathrm{~h}$ of treatment with (B) free GlaB or (C) NC-GlaB was determined by MTT assay. Results, expressed as percentage to control untreated cells, correspond to mean \pm SD of five different experiments.

GlaB: Glabrescione B; NC: Nanocapsule; NC-GlaB: GlaB-loaded oil-cored polymeric nanocapsule; SD: Standard deviation.

Biodistribution of radiolabeled NC-PEG-GlaB in mice after single intravenous injection The biodistribution of radiolabeled NC-PEGDTPA-GlaB was investigated in pancreatic-tumorbearing SCID/Beige mice. After receiving a single tail vein injection of NCs ( $370 \mu \mathrm{g}$ GlaB per mouse), the animals were sacrificed at $30 \mathrm{~min}$ or $24 \mathrm{~h}$ postinjection and the $\% \mathrm{ID} / \mathrm{g}$ of tissue and $\%$ ID/organ were calcu- lated. As shown in Figure 7B \& C, NCs showed accumulation in major first-pass organs such as liver and spleen at $24 \mathrm{~h}$ after injection. Tumor uptake was 1.2 and $0.3 \% \mathrm{ID} / \mathrm{g}$ at $30 \mathrm{~min}$ and $24 \mathrm{~h}$, respectively. Mice were not perfused before sacrifice. It is therefore likely that the higher $\% \mathrm{ID} / \mathrm{g}$ tumor obtained at $30 \mathrm{~min}$ than $24 \mathrm{~h}$ is due to high concentration of the drug in the blood. 


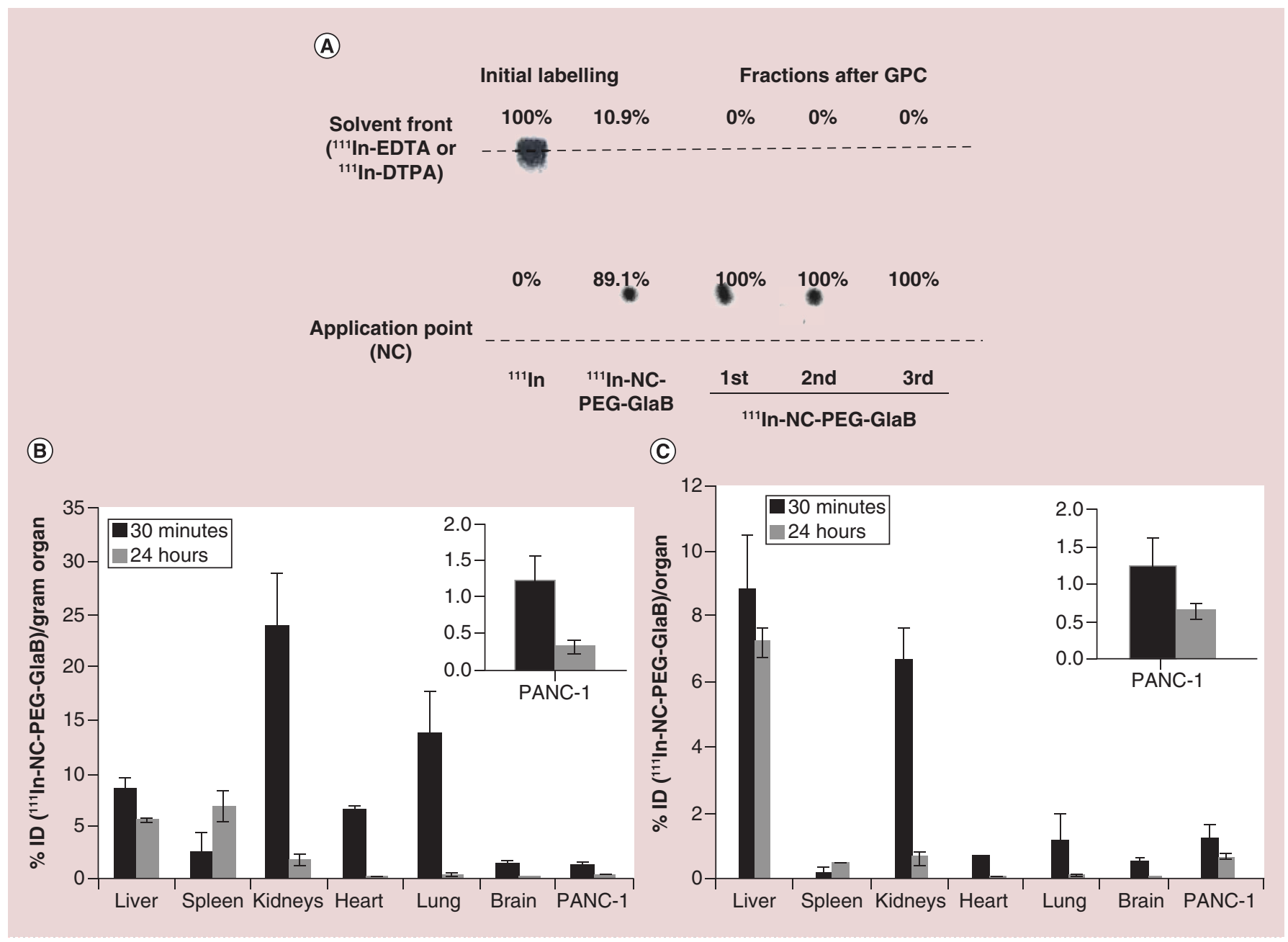

Figure 7. Radiolabeling of NC-PEG with ${ }^{111}$ In, stability and in vivo biodistribution. (A) TLC of the radiolabeled NCs immediately after radiolabeling and after desalting using PD10 desalting column, after concentrating the sample and just prior injection. No free ${ }^{111}$ In was detected in all the samples. A single dose of radiolabeled NCs was administered to SCID/Beige mice, via tail vein. (B) Percentage injected dose per gram of organ (\% ID/g of organ) and (C) percentage injected dose per organ (\% ID/organ), at 0.5 and $24 \mathrm{~h}$ after injection of $370 \mu \mathrm{g} \mathrm{GlaB} / \mathrm{mouse}$. Insets show the uptake in tumors. Data were expressed as means \pm standard deviation $(n=2)$. GlaB: Glabrescione B; ID: Injected dose; NC: Nanocapsule.

\section{Histological examination of major organs} following multiple injections of radiolabeled NC-PEG-GlaB in mice

To evaluate the systemic toxicity of radiolabeled NC-PEG-DTPA-GlaB, pancreatic tumor-bearing SCID/Beige mice were injected with the NCs ( $250 \mu \mathrm{g} \mathrm{GlaB} /$ mouse), via tail vein, once a week for 3 consecutive weeks. Histological analysis, carried out on hematoxylin and eosin stained tissue sections, did not show significant changes in lung, heart, kidney, liver and spleen compared with untreated (naive) tissues (Figure 8). This initially suggests that the NC-PEG-GlaB formulation can be administered via systemic injection. Extensive biocompatibility studies of this nanoformulation need to be assessed in the future.

\section{Discussion}

CSCs are emerging as key therapeutic targets in oncology, as their efficient elimination may offer long-lasting tumor remission or even potentially disease-free treatment outcomes for patients. In this regard, a substantial amount of evidence suggests that CSCs rely on ligand-receptor-mediated signaling pathways, namely $\mathrm{Hh}$, Wnt and Notch, for strict control of cellular functions that impart cell fate, namely proliferation, self-renewal and differentiation [44,45]. Aberrant $\mathrm{Hh}$ signaling is found in the majority of the human cancers, including brain tumors [18], and is usually caused not only by mutations in Hh pathway components (e.g., receptors) but also by high expression of $\mathrm{Hh}$ ligands [13], Hh signaling, which plays an important role in stem cell renewal, is epigenetically regulated in 


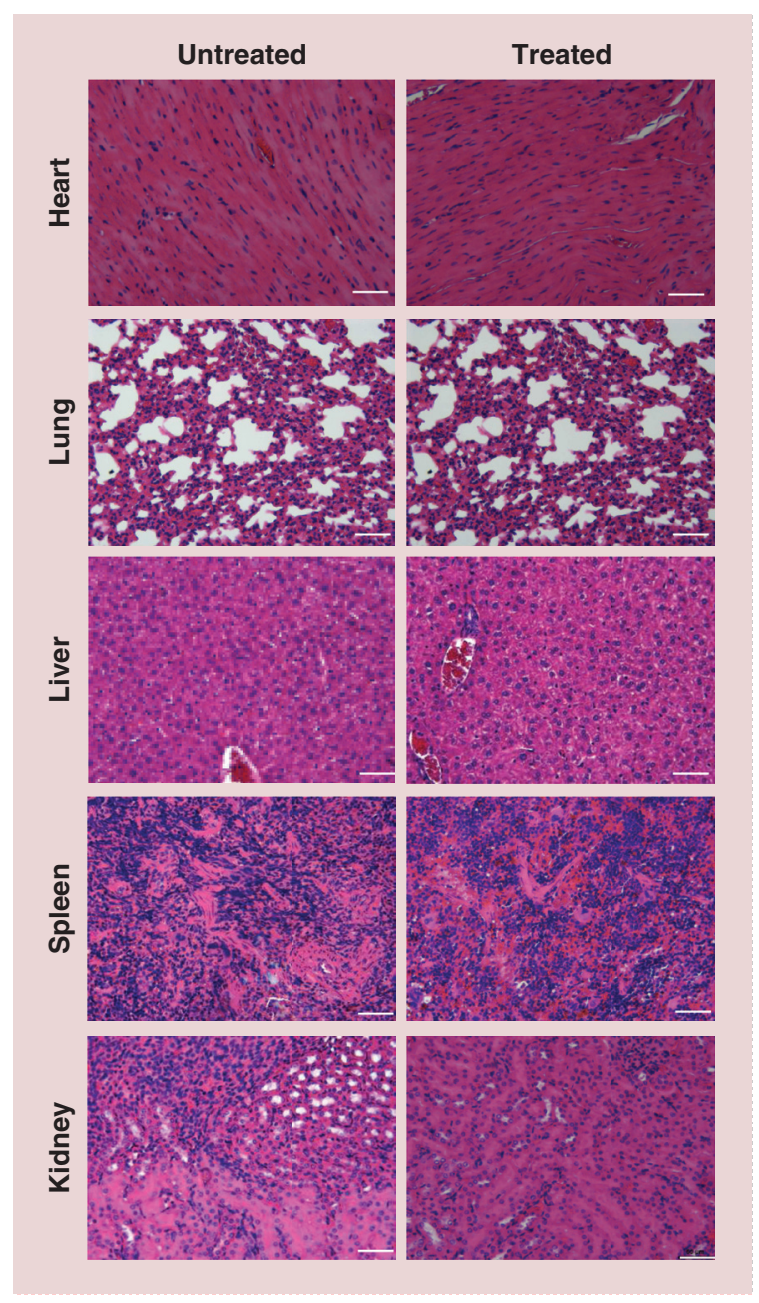

Figure 8. Organ histology for NSG (NOD/SCID gamma) mice treated with multiple nanocapsule injections. NSG mice were injected intravenously with $250 \mu \mathrm{g}$ of NCformulated GlaB once a week for 3 weeks. After the mice were sacrificed, the organs were immediately fixed in $10 \%$ neutral buffer formalin as $5 \mathrm{~mm}^{2}$ pieces. These pieces were then paraffin-embedded, sectioned for hematoxylin and eosin stains and imaged with light microscopy. Scale corresponds to $50 \mu \mathrm{m}$. GlaB: Glabrescione B; NC: Nanocapsule.

CSCs mainly Gli transcription factors [46]. Targeting Hh signaling components or epigenetic regulators in CSC-driven tumors could therefore be of therapeutic interest.

To date, an inhibitor of $\mathrm{Hh}$ pathway receptor (Smo) - GDC-0449 - has been approved by US FDA and is currently used in clinics, whereas only a few Gli inhibitors have been identified [47,48]. Therefore, novel drugs targeting Gli family members or downstream effectors would be beneficial for a wide spectrum of patients whose tumors have high Gli protein levels and/or activity. Furthermore, downstream activation of Gli function has been reported [49], with the development of resistance to Smo antagonists being observed fre- quently during therapy. Recent in silico and in vitro screens of a library of natural compounds identified a lead candidate for Gli inhibition - GlaB [22]. GlaB, bearing the 5,7-dimethoxyisoflavone nucleus, was isolated and characterized from the seeds of D. glabrescens, a Brazilian plant, in 1977 by Delle Monache et al. [21]. Since developed extraction methods allow us to get very limited amounts of pure isoflavone, here we provided the first total synthesis of $\mathrm{GlaB}$ which foresees a six-step route with an overall yield of $7 \%$.

The in vitro and in vivo GlaB activities were also tested in our previous study, with results showing impaired Hh oncogenic activity via inhibition of Gli1/ DNA interaction [22]. This provided proof of concept for the therapeutic relevance of an Hh-targeting approach focused on a downstream Gli effector rather than on upstream oncogenic deregulated signals. However, the native GlaB molecule is insoluble in water (solubility is $0.02 \mu \mathrm{g} / \mathrm{ml}$ ), which will likely translate into poor bioavailability in vivo. In a previous study from our group, the efficacy of GlaB against MB-bearing and BCC-bearing mice was assessed [22]. A solution of GlaB, prepared in 2-hydroxypropyl- $\beta$ cyclodextrin:ethanol (3:1), was injected subcutaneously, compromising drug bioavailability. In this study, the use of ethanol was replaced with the long-circulating NC-GlaB, allowing intravenously injection of relatively high GlaB dose.

We have previously developed PEG-conjugated polymeric oil-cored NCs to enhance systemic delivery of therapeutic agents and active natural compounds as quercetin and curcumin [27,28]. Increased tumor uptake of folic-acid-conjugated NCs, containing quercetin, was observed after intravenous administration of in mice via passive and active targeting, while passively targeted curcumin-loaded PEG-PLGA NCs enhanced curcumin release into the tumor site after systemic administration, when compared with the free drug [28]. According to these studies, in an attempt to formulate NCs characterized by smallest size, narrowest PDI, higher colloidal stability and drug loading, different oil-cored types were used [28]. Among all, castor oil was found to be the one capable of obtaining the desired NCs [28]; thus, it has been selected as the most promising system to enhance GlaB bioavailability. In particular, GlaB was successfully loaded into NCs composed of castor-oil-cored offering approximately 70 -fold increase in $\mathrm{GlaB}$ aqueous solubility (solubility in NC: $\sim 700 \mu \mathrm{g} \mathrm{GlaB} / \mathrm{ml}$ of $\mathrm{NC}$ ). Regarding the choice of the polymer, different PLGA polymer derivatives were used depending on the experiment that needed to be performed. Both PEG-PLGA and DTPA-PEGPLGA were obtained through organic synthesis [28] and, in accordance with the previous studies $[27,28]$, 
the conjugation of PLGA with PEG leads to a slight increase (less negative) in surface charge of NC-PEG and NC-PEG-GlaB, probably due to neutralization of the negative carboxylate groups of PLGA (Table 1 \& Supplementary Table 1). Importantly, empty NCs and NC-GlaB showed similar hydrodynamic size and stability over time, which suggests that the encapsulation of GlaB does not affect NC size and long-term storage. Comparable biological evaluation results were obtained for both NC and NC-PEG (Supplementary Figure 4) when tested in IENS at the three time points. The good in vitro serum stability data $(<20 \%$ release over $24 \mathrm{~h}$ ) suggest that there will be minimal drug release from the NC in blood circulation and that most of the drug will be released at the target site, in other words, the tumor.

A series of in vitro functional assays were then performed to evaluate and compare the anticancer properties of NC-GlaB and free GlaB. Cell lines for these studies were chosen, after literature consultation, on the basis of Hh status (dysregulated Hh pathway) and presence of stem-like cells in the cell population. In vitro results obtained from cell viability, cell cycle analysis and western blotting confirmed that CSC cell lines (G7, IENS) were more sensitive to GlaB than non-stem cancer cells (GL261, PANC1 and SKOV3), an effect that was mediated by $\mathrm{Hh}$ regulator $\mathrm{Gli}$, which is more pronounced in CSCs. This was further confirmed by the fact that differentiated G7 cells were drug insensitive. Future studies will be performed to prove unequivocally that $\mathrm{Hh}$ signaling is dysregulated in the CSCs used in this study (G7, IENS).

The fact that GlaB was effective in killing CSCs at very low concentrations $(\sim 70 \%$ cell killing with $1 \mu \mathrm{M}$ for $48 \mathrm{~h}$ ) is very encouraging and suggests a promising in vivo therapeutic outcome if such concentrations can be achieved in vivo following systemic injection. Moreover, these results are consistent with previous in vitro studies, in which $\mathrm{GlaB}(5 \mu \mathrm{M})$ was shown to inhibit proliferation of ex vivo cultured mouse granule cell progenitors, MB stem cells isolated from Ptch1 ${ }^{ \pm}$ mice tumors and ASZ001 BCC cells, with a strength similar to GANT61 $(10 \mu \mathrm{M})$ [22]. Indeed, GANT61 has become the reference compound for CSC-targeted therapies as it proved to inhibit the Hh pathway at Gli level in several cancer cells, CSCs and tumor animal models, such as pancreatic [17], prostate [14], lung [12], colon and hepatocellular cancer [50,51], as well as in tumors for which the role of Gli was not elucidated before, including ovarian cancer [52], esophageal adenocarcinoma and melanoma [8,53]. However, GANT61 inhibits Gli-mediated transcription by an unclear mechanism - most likely by inducing posttranslational modifications of Gli - with a reported
$\mathrm{IC}_{50}$ of $5 \mu \mathrm{M}$ (in HEK293 cell line). In our study, GlaB and NC-GlaB were shown to be more effective than GANT61 in inducing tumor cell death, with $\mathrm{IC}_{50}$ values in PANC1 of 1.62 and $1.49 \mu \mathrm{M}$, respectively.

Following up the positive in vitro studies, it was necessary to overcome the poor water solubility and bioavailability of GlaB so that it can be validated for clinical application. Our previous studies assessed organ distribution of PEG-NCs in a leaky solid tumor model - CT26 colon cancer - and approximately $0.8 \%$ $\mathrm{ID} / \mathrm{g}$ of tissue in tumors was achieved $24 \mathrm{~h}$ postinjection [28]. Furthermore, curcumin, used as an anticancer drug in that study, has shown to be delivered to the tumor at therapeutic concentrations leading to significant tumor growth delay [28]. In preparation for preclinical testing of therapeutic activity, we first assessed organ biodistribution in PANC1-tumor-bearing mice. This tumor model is known to be highly resistant and not sufficiently leaky [17]. Such data will give us some guidance on the next stages required to prepare glioma-targeting NC formulation to deliver GlaB to brain cancer. Our results have shown that values of $0.5-1.25 \% \mathrm{ID} / \mathrm{g}$ tissues were achieved in tumors $24 \mathrm{~h}$ postinjection. Taking into account the fact that the dose administered was approximately $370 \mu \mathrm{g} \mathrm{GlaB}$ per mouse, one would expect that drug concentrations in the tumor to be approximately $1.9-4.4 \mu \mathrm{g} / \mathrm{g}$ tumor $(4-10 \mathrm{nM})$. These concentrations are below the therapeutic concentrations used in PANC1, and it is therefore suggested that higher or multiple doses of the formulation is required.

The results obtained from this work gave us some guidance on the next stages, to use NCs in a leaky tumor. We are also currently working on reducing the size of our NCs to less than $150 \mathrm{~nm}$ as smaller sizes are expected to have better extravasation than $200 \mathrm{~nm}$ NCs, before testing them in other tumor models for therapy. Moreover, the therapeutic efficacy of these NCs will be tested against CSCs isolated from other types of tumor, such as pancreas, or Hh-driven tumors such as MB.

\section{Conclusion}

The efficient encapsulation of $\mathrm{GlaB}$ into oil-cored NCs (NC-GlaB) greatly improved the bioavailability and potential clinical application of this drug. More importantly, NC-GlaB retained the same antitumoral activity of the free drug, both revealing remarkable cell killing activity against Hh-dependent CSC lines and, to a lesser extent, non-stem cancer cells. Substantial evidence is provided for a nanoparticle-based drug with good circulation profile that could be useful as part of a multimodal treatment for patients affected by Hh-dependent CSC-driven tumors. 
Supplementary data

To view the supplementary data that accompany this paper please visit the journal website at: www.futuremedicine.com/ doi/full/10.2217/nnm-2016-0388

\section{Acknowledgements}

The authors would like to acknowledge networking contribution by the COST Action CM-1407 'Challenging organic syntheses inspired by nature - from natural products chemistry to drug discovery.'

Financial \& competing interests disclosure

The authors would like to acknowledge financial support from Center for Life Nano Science@Sapienza, Istituto Italiano di Tecnologia (IIT), Roma, Italy, Ministero dell'Istruzione, dell'Università e della Ricerca (PRIN project 2014). Funding from Wellcome Trust (WT103913), Worldwide Cancer Research (12-1054) and EU FP7-ITN Marie-Curie Network programme RADDEL (290023) is acknowledged. PM Costa is a Sir Henry Wellcome postdoctoral fellow (WT103913). SM Pollard is a Cancer research UK Senior Research Fellow (A17368). The authors have no other relevant affiliations or financial involvement with any organization or entity with a financial interest in or financial conflict with the subject matter or materials discussed in the manuscript apart from those disclosed.

No writing assistance was utilized in the production of this manuscript.

Ethical conduct of research

The authors state that they have obtained appropriate institutional review board approval or have followed the principles outlined in the Declaration of Helsinki for all human or animal experimental investigations. In addition, for investigations involving human subjects, informed consent has been obtained from the participants involved.

\section{Open access}

This article is distributed under the terms of the Creative Commons Attribution License 4.0 which permits any use, distribution, and reproduction in any medium, provided the original author(s) and the source are credited. To view a copy of the license, visit http://creativecommons.org/licenses/by/4.0/

Executive summary

Background

- Use of PEG-conjugated polymeric oil-cored nanocapsules (NCs) to enhance systemic delivery of glabrescione B (GlaB).

Synthesis of GlaB

- The total synthesis of GlaB in six steps with an overall yield of $7 \%$ is reported for the first time.

Physico-chemical characterization of NCs

- GlaB was successfully loaded into NCs composed of castor-oil-cored NCs offering approximately 70-fold increase in GlaB aqueous solubility.

- Hydrodynamic diameter, polydispersity index, $\zeta$ potential and stability were determined.

- In vitro serum stability data suggest that there will be minimal drug release from the NC in blood circulation and that most of the drug will be released at the target site, in other words, the tumor.

In vitro functional assays

- Cell viability, cell cycle analysis and western blotting confirmed that cancer stem cell lines (G7, IENS) were more sensitive to GlaB than non-stem cancer cells (GL261, PANC1 and SKOV3).

- Differentiated G7 cells were drug insensitive as they could be less dependent on Hh pathway.

In vivo biodistribution

- The biodistribution of radiolabeled NC-GlaB was investigated in pancreatic-tumor-bearing SCID/Beige mice and $0.5-1.25 \% \mathrm{ID} / \mathrm{g}$ tissues were achieved in tumors at $24 \mathrm{~h}$ postinjection.

\section{References}

1 Takebe N, Harris PJ, Warren RQ, Ivy SP. Targeting cancer stem cells by inhibiting Wnt, Notch, and Hedgehog pathways. Nat. Rev. Clin. Oncol. 8(2), 97-106 (2011).

2 Chen K, Huang YH, Chen JL. Understanding and targeting cancer stem cells: therapeutic implications and challenges. Acta Pharmacol. Sin. 34(6), 732-740 (2013).

3 Reya T, Morrison SJ, Clarke MF, Weissman IL. Stem cells, cancer, and cancer stem cells. Nature 414(6859), 105-111 (2001).

4 Manoranjan B, Venugopal C, Mcfarlane N et al. Medulloblastoma stem cells: modeling tumor heterogeneity. Cancer Lett. 338(1), 23-31 (2013).
5 Berman DM, Karhadkar SS, Hallahan AR et al. Medulloblastoma growth inhibition by hedgehog pathway blockade. Science 297(5586), 1559-1561 (2002).

6 Graab U, Hahn H, Fulda S. Identification of a novel synthetic lethality of combined inhibition of hedgehog and PI3K signaling in rhabdomyosarcoma. Oncotarget 6(11), 8722-8735 (2015).

7 Roberts WM, Douglass EC, Peiper SC, Houghton PJ, Look AT. Amplification of the gli gene in childhood sarcomas. Cancer Res. 49(19), 5407-5413 (1989).

8 Stecca B, Mas C, Clement V et al. Melanomas require HEDGEHOG-GLI signaling regulated by interactions between GLI1 and the RAS-MEK/AKT pathways. Proc. Natl Acad. Sci. USA 104(14), 5895-5900 (2007). 
9 Tojo M, Kiyosawa H, Iwatsuki K, Kaneko F. Expression of a sonic hedgehog signal transducer, hedgehog-interacting protein, by human basal cell carcinoma. Br. J. Dermatol. 146(1), 69-73 (2002).

10 Kubo M, Nakamura M, Tasaki A et al. Hedgehog signaling pathway is a new therapeutic target for patients with breast cancer. Cancer Res. 64(17), 6071-6074 (2004).

11 Huang S, He J, Zhang X et al. Activation of the hedgehog pathway in human hepatocellular carcinomas. Carcinogenesis 27(7), 1334-1340 (2006).

12 Huang L, Walter V, Hayes DN, Onaitis M. Hedgehog-GLI signaling inhibition suppresses tumor growth in squamous lung cancer. Clin. Cancer Res. 20(6), 1566-1575 (2014).

13 Watkins DN, Berman DM, Burkholder SG, Wang B, Beachy PA, Baylin SB. Hedgehog signalling within airway epithelial progenitors and in small-cell lung cancer. Nature 422(6929), 313-317 (2003).

14 Lauth M, Bergstrom A, Shimokawa T, Toftgard R. Inhibition of GLI-mediated transcription and tumor cell growth by small-molecule antagonists. Proc. Natl Acad. Sci. USA 104(20), 8455-8460 (2007).

15 Sanchez P, Hernandez AM, Stecca B et al. Inhibition of prostate cancer proliferation by interference with SONIC HEDGEHOG-GLI1 signaling. Proc. Natl Acad. Sci. USA 101(34), 12561-12566 (2004).

16 Clement V, Sanchez P, De Tribolet N, Radovanovic I, Ruiz I Altaba A. HEDGEHOG-GLI1 signaling regulates human glioma growth, cancer stem cell self-renewal, and tumorigenicity. Curr. Biol. 17(2), 165-172 (2007).

$17 \mathrm{Fu}$ J, Rodova M, Roy SK et al. GANT-61 inhibits pancreatic cancer stem cell growth in vitro and in NOD/SCID/IL2R gamma null mice xenograft. Cancer Lett. 330(1), 22-32 (2013).

18 Kiesslich T, Berr F, Alinger B et al. Current status of therapeutic targeting of developmental signalling pathways in oncology. Curr. Pharm. Biotechnol. 13(11), 2184-2220 (2012).

19 Thayer SP, Di Magliano MP, Heiser PW et al. Hedgehog is an early and late mediator of pancreatic cancer tumorigenesis. Nature 425(6960), 851-856 (2003).

20 Botta B, Gulino A, Botta M et al.: WO207069 (2014).

21 Delle Monache F, Cairo Valeira G, Sialer De Zapata D, Marini-Bettolo GB. 3-Aryl-4-methoxycoumarins and isoflavones from Derris glabrescens. Gazz. Chim. Ital. 107, 5 (1977).

22 Infante $\mathrm{P}$, Mori M, Alfonsi R et al. Gli1/DNA interaction is a druggable target for hedgehog-dependent tumors. EMBO J. 34(2), 200-217 (2015).

23 Shieh YA, Yang SJ, Wei MF, Shieh MJ. Aptamer-based tumor-targeted drug delivery for photodynamic therapy. ACS Nano 4(3), 1433-1442 (2010).

24 Wang T, He N. Preparation, characterization and applications of low-molecular-weight alginate-oligochitosan nanocapsules. Nanoscale 2(2), 230-239 (2010).

25 Yurgel V, Collares T, Seixas F. Developments in the use of nanocapsules in oncology. Braz. J. Med. Biol. Res. 46(6), 486-501 (2013).
26 Moinard-Checot D, Chevalier Y, Briancon S, Fessi H, Guinebretiere S. Nanoparticles for drug delivery: review of the formulation and process difficulties illustrated by the emulsion-diffusion process. J. Nanosci. Nanotechnol. 6(9-10), 2664-2681 (2006).

27 El-Gogary RI, Rubio N, Wang JT et al. Polyethylene glycol conjugated polymeric nanocapsules for targeted delivery of quercetin to folate-expressing cancer cells in vitro and in vivo. ACS Nano 8(2), 1384-1401 (2014).

28 Klippstein R, Wang JT, El-Gogary RI et al. Passively targeted curcumin-loaded PEGylated PLGA nanocapsules for colon cancer therapy in vivo. Small 11(36), 4704-4722 (2015).

29 Fessi HPF, Devissaguet J, Ammoury N, Benita S. Nanocapsule formation by interfacial polymer deposition following solvent displacement. Int. J. Pharm. 55, 4 (1989).

30 Anuchapreeda S, Fukumori Y, Okonogi S, Ichikawa H. Preparation of lipid nanoemulsions incorporating curcumin for cancer therapy. J. Nanotechnol. 2012, 11 (2011).

31 Bruggeman SW, Hulsman D, Tanger E et al. Bmil controls tumor development in an Ink4a/Arf-independent manner in a mouse model for glioma. Cancer Cell 12(4), 328-341 (2007).

32 Fael Al-Mayhani TM, Ball SL, Zhao JW et al. An efficient method for derivation and propagation of glioblastoma cell lines that conserves the molecular profile of their original tumours. J. Neurosci. Methods 176(2), 192-199 (2009).

33 Pollard SM, Yoshikawa K, Clarke ID et al. Glioma stem cell lines expanded in adherent culture have tumor-specific phenotypes and are suitable for chemical and genetic screens. Cell Stem Cell 4(6), 568-580 (2009).

34 Stricker SH, Feber A, Engstrom PG et al. Widespread resetting of DNA methylation in glioblastoma-initiating cells suppresses malignant cellular behavior in a lineagedependent manner. Genes Dev. 27(6), 654-669 (2013).

35 Carén $\mathrm{H}$, Stricker SH, Bulstrode $\mathrm{H}$ et al. Glioblastoma stem cells respond to differentiation cues but fail to undergo commitment and terminal cell-cycle arrest. Stem Cell Reports 5(5), 829-842 (2015).

36 Vasselin DA, Westwell AD, Matthews CS, Bradshaw TD, Stevens MF. Structural studies on bioactive compounds. 40.(1) Synthesis and biological properties of fluoro-, methoxyl-, and amino-substituted 3-phenyl-4H-1benzopyran-4-ones and a comparison of their antitumor activities with the activities of related 2-phenylbenzothiazoles. J. Med. Chem. 49(13), 3973-3981 (2006).

37 Ramarao C, Ley SV, Smith SC, Shirley IM, Dealmeida $\mathrm{N}$. Encapsulation of palladium in polyurea microcapsules. Chem. Commun. (Camb)10 1132-1133 (2002).

38 Lee CKY, Holmes AB, Ley SV et al. Efficient batch and continuous flow Suzuki cross-coupling reactions under mild conditions, catalysed by polyurea-encapsulated palladium (II) acetate and tetra-n-butylammonium salts. Chem. Commun. (Camb.) 16, 2175-2177 (2005).

39 Ye YQ, Koshino H, Onose J, Yoshikawa K, Abe N, Takahashi $\mathrm{S}$. Expeditious synthesis of vialinin B, an extremely potent inhibitor of TNF-alpha production. Org. Lett. 11(21), 5074-5077 (2009). 
40 Basabe P, De Roman M, Marcos IS et al. Prenylflavonoids and prenyl/alkyl-phloroacetophenones: synthesis and antitumour biological evaluation. Eur. J. Med. Chem. 45(9), 4258-4269 (2010).

41 Arai MA, Akamine R, Sadhu SK, Ahmed F, Ishibashi M. Hedgehog/GLI-mediated transcriptional activity inhibitors from Crinum asiaticum. J. Nat. Med. 69(4), 538-542 (2015).

42 Liao X, Siu MK, Au CW et al. Aberrant activation of hedgehog signaling pathway in ovarian cancers: effect on prognosis, cell invasion and differentiation. Carcinogenesis 30(1), 131-140 (2009).

43 Yan GN, Yang L, Lv YF et al. Endothelial cells promote stem-like phenotype of glioma cells through activating the Hedgehog pathway. J. Pathol. 234(1), 11-22 (2014).

44 Borah A, Raveendran S, Rochani A, Maekawa T, Kumar DS. Targeting self-renewal pathways in cancer stem cells: clinical implications for cancer therapy. Oncogenesis 4, e177 (2015).

45 Karamboulas C, Ailles L. Developmental signaling pathways in cancer stem cells of solid tumors. Biochim. Biophys. Acta 1830(2), 2481-2495 (2013).

46 Ruiz I Altaba A, Sanchez P, Dahmane N. Gli and hedgehog in cancer: tumours, embryos and stem cells. Nat. Rev. Cancer 2(5), 361-372 (2002).

47 Infante P, Alfonsi R, Botta B, Mori M, Di Marcotullio L. Targeting GLI factors to inhibit the Hedgehog pathway. Trends Pharmacol. Sci. 36(8), 547-558 (2015).
48 Mas C, Ruiz I Altaba A. Small molecule modulation of $\mathrm{HH}-$ GLI signaling: current leads, trials and tribulations. Biochem. Pharmacol. 80(5), 712-723 (2010).

49 Dijkgraaf GJ, Alicke B, Weinmann L et al. Small molecule inhibition of GDC-0449 refractory smoothened mutants and downstream mechanisms of drug resistance. Cancer Res. 71(2), 435-444 (2011).

50 Mazumdar T, Devecchio J, Agyeman A, Shi T, Houghton JA. Blocking Hedgehog survival signaling at the level of the GLI genes induces DNA damage and extensive cell death in human colon carcinoma cells. Cancer Res. 71(17), 5904-5914 (2011).

51 Wang Y, Han C, Lu L, Magliato S, Wu T. Hedgehog signaling pathway regulates autophagy in human hepatocellular carcinoma cells. Hepatology 58(3), 995-1010 (2013).

52 Chen Q, Xu R, Zeng C et al. Down-regulation of Gli transcription factor leads to the inhibition of migration and invasion of ovarian cancer cells via integrin beta4-mediated FAK signaling. PLoS ONE 9(2), e88386 (2014).

53 Kebenko M, Drenckhan A, Gros SJ et al. ErbB2 signaling activates the Hedgehog pathway via PI3K-Akt in human esophageal adenocarcinoma: identification of novel targets for concerted therapy concepts. Cell Signal. 27(2), 373-381 (2015). 